\title{
A dynamic model for generating small-scale heterogeneities in ocean floor basalts
}

\author{
Daniel Bideau and Roger Hékinian \\ Department of Marine Geosciences, IFREMER (Institut Français de Recherche pour l'exploitation de la MER) \\ Plouzané, France
}

\begin{abstract}
Small-scale distribution of basaltic compositions along the mid-ocean ridge crests suggests that the magmatic processes are sensitive to spatial and temporal fluctuations related to proximity of ridge hot spots, changes in spreading rate, thermal boundary effects associated with ridge offsets, off-axis volcanoes and ridge propagators, and variations in magma supply through time. A detailed sampling of the East Pacific Rise (EPR) axis, near $13^{\circ} \mathrm{N}$, revealed that complex basalt compositional variations unrelated to morphology and structure occur both on the ridge axis and on nearby off-axis seamounts. This small-scale heterogeneity is attributed to successive magmatic cycles separated by periods of quiescence (amagmatic phases) where each cycle involves several melting stages of a composite mantle source, interrupted by extraction and a rapid migration of the melt toward the upper levels of the lithosphere. For a given composition of the mantle source, this process will produce primitive melts which are progressively depleted in incompatible elements. The final contrast in composition between the various extruded magmas depends on the opposing effects of mixing and fractionation during transport toward the ocean floor. A multistage melt extraction model for trace elements, based on nonmodal near-fractional melting ( $1 \%$ increments) with three steps of accumulation $(<2.5-5 \%)$ and extraction above the melting region, gives reliable results for less than 8-13\% total melting of a spinel-lherzolite (olivine $49-55 \%$, orthopyroxene $25-29 \%$, clinopyroxene $18-21 \%$, spinel $1-2 \%$ ). This partial melting model is only partly constrained on the basis of available chemical and physical data, as well as laboratory experiments, and it has several implications for the dynamics of the upper mantle and the lower crust which are not taken into account by present-day physical models. The major consequences of this model are the introduction of discontinuities in the melting regime and the cyclicity of magma production.
\end{abstract}

\section{Introduction}

Correlations between large-scale compositional variations in oceanic basalts and the main geodynamic environments that characterize the oceans have long been recognized [e.g., Gilluly, 1971]. The particular affinities of calc-alkaline series, alkaline suites, and tholeiites for convergent plate margins, intraplate island chains, or mid-ocean ridges [Green, 1971; Pearce and Cann, 1973] were used in order to discriminate between the various types of ophiolite complexes [Pearce and Cann, 1971; Shervais, 1982]. Medium scale compositional variations associated with mid-ocean ridge hot spots or mantle plumes, such as the Azores plateau or the Galapagos islands [Schilling, 1973; Clague et al., 1981] were ascribed to regional mantle heterogeneities [White and Schilling, 1978; Bougault et al., 1979]. Other evidence of axial compositional evolution with spreading rate [Bass, 1971; Morel and Hekinian, 1980] suggests that petrogenesis is partly controlled by variations in the thermal budget at the axes of mid-ocean ridges [Scheidegger, 1973]. Global correlations of the ocean ridge basalt chemistry with axial depth and crustal thickness were also related to the depth of melting in the mantle [Klein and Langmuir, 1987].

Copyright 1995 by the American Geophysical Union.

Paper number 94JB03102.

0148-0227/95/94JB-03102\$05.00
On a smaller scale, spatial compositional zonations on midocean ridges were attributed to crystal fractionation processes in a large steady state magma chamber [Bryan et al., 1979; Hekinian and Walker, 1987]. This interpretation, predicted by simple conduction models of the thermal structure of the lithosphere [Sleep, 1975], was corroborated by studies on ophiolite complexes such as in Oman [Pallister and Hopson, 1981]. However, geophysical experiments on mid-ocean ridges have not located magma chambers beneath slow and intermediate spreading ridges [McClain and Lewis, 1982; Purdy and Detrick, 1986]. The only evidence of a low-velocity zone suggesting the presence of a magma chamber is found underneath fast (total rate $>10 \mathrm{~cm} / \mathrm{yr}$ ) spreading centers [Kent et al., 1990; Burnett et al., 1989]. Such a magma reservoir must be short lived and/or should have a smaller dimension than predicted by simple thermal conduction [Detrick et al., 1987]. Intense hydrothermal convection in the vicinity of the ridge axis [Wolery and Sleep. 1976; Lister, 1977] probably contributes to a rapid cooling of the lithosphere. Consequently, several models based on the presence or the absence of a magma chamber at the base of the oceanic crust were proposed; most of them were intermediate between the "infinite onion" (large zoned magma chamber) and the "infinite leek" (small unconnected magma reservoirs) models [Nisbet and Fowler, 1978].

The existence of along-strike variations were related to fluctuations in the magma chamber geometry as the result of ridge segmentation by overlapping spreading centers and transform fault offsets [Christie and Sinton, 1981; Langmuir et al., 1986]. 
These variations were principally attributed to changes in the total amount of melting of heterogeneous mantle, with a variable extent of mixing in shallow magma chambers. The lack of clear relationships between structural setting and other smallscale variations in incompatible element and isotopic compositions of the volcanics erupted on segments of the East Pacific Rise (EPR) axis and on off-axial seamounts was also noted [Hékinian et al., 1989]. The variations in incompatible element ratios might simply result from a multistage melt extraction process in a lherzolitic mantle [Hékinian et al., 1989], but the radiogenic isotopes suggest that a veined mantle made of pyroxenite layers or lenses enclosed in lherzolites might be more appropriate [Prinzhofer et al., 1989].

The main objectives of the present study are to develop this concept of multiphase melting of a composite mantle at $13^{\circ} \mathrm{N}$ on the EPR and to propose some possible processes for explaining discontinuous extraction of melt from the melting zone (the "melting pulse" hypothesis). Finally, we will explore the consequences and the limitations of these concepts when compared to current physico-chemical models of magma generation and when applied to the various petrogenetic systems encountered on mid-ocean ridges.

\section{Dynamics of Magma Generation at $13^{\circ} \mathrm{N}$ on the EPR}

Detailed submersible work (about 40 dives) on the EPR segment located near $12^{\circ} 50 \mathrm{~N}$ and on the adjacent off-axial seamounts within 1 to $20 \mathrm{~km}$ apart recorded similar petrological diversity which does not correlate with the geological settings [Hekinian et al., 1989]. The K/Ti ratios (Figure 1a) of the sampled basaltic glasses range from enriched (undepleted) to normal (depleted and transitional) mid-ocean ridge basalts (EMORBs to N-MORBs). Part of this variability might be explained by fractionation processes in shallow magmatic reservoirs, but the distribution of bulk rare earth element (REE) contents and other incompatible element ratios (Figures $1 \mathrm{~b}$ and 1c) suggests that deep-seated processes are also involved. Both small-scale mantle heterogeneities and variations in the amount of melting are able to produce some basalt diversity. The contribution of mantle heterogeneities to basalt diversity at $12^{\circ} 50 \mathrm{~N}$ on the EPR is particularly emphasized by the distribution of radiogenic isotope ratios [Prinzhofer et al., 1989]. Hékinian et al. [1989] proposed a scheme involving successive magmatic cycles including several (three) steps of partial melting (magmatic events) of a composite mantle source to account for this kind of complex distribution (Figure 2). In order to prevent extensive mixing at depth, the authors considered that each magmatic cycle is followed by a period of quiescence (an amagmatic period) and that two magmatic events are separated by rapid melt segregation toward the lithosphere. Since melting steps might occur at various levels in the mantle, this concept presents some affinities with the "dynamic melting" model of Langmuir et al. [1977]. However, the multistage melt extraction model is a discontinuous process which is time dependent, whereas the dynamic melting as described by Langmuir et al. [1977] is continuous and steady state.

\section{The Multistage Melt Extraction Hypothesis}

Basic concepts and major physical constraints. Several studies previously suggested that the ocean floor basalts originate from multiphase melting of the mantle [e.g., Duncan and
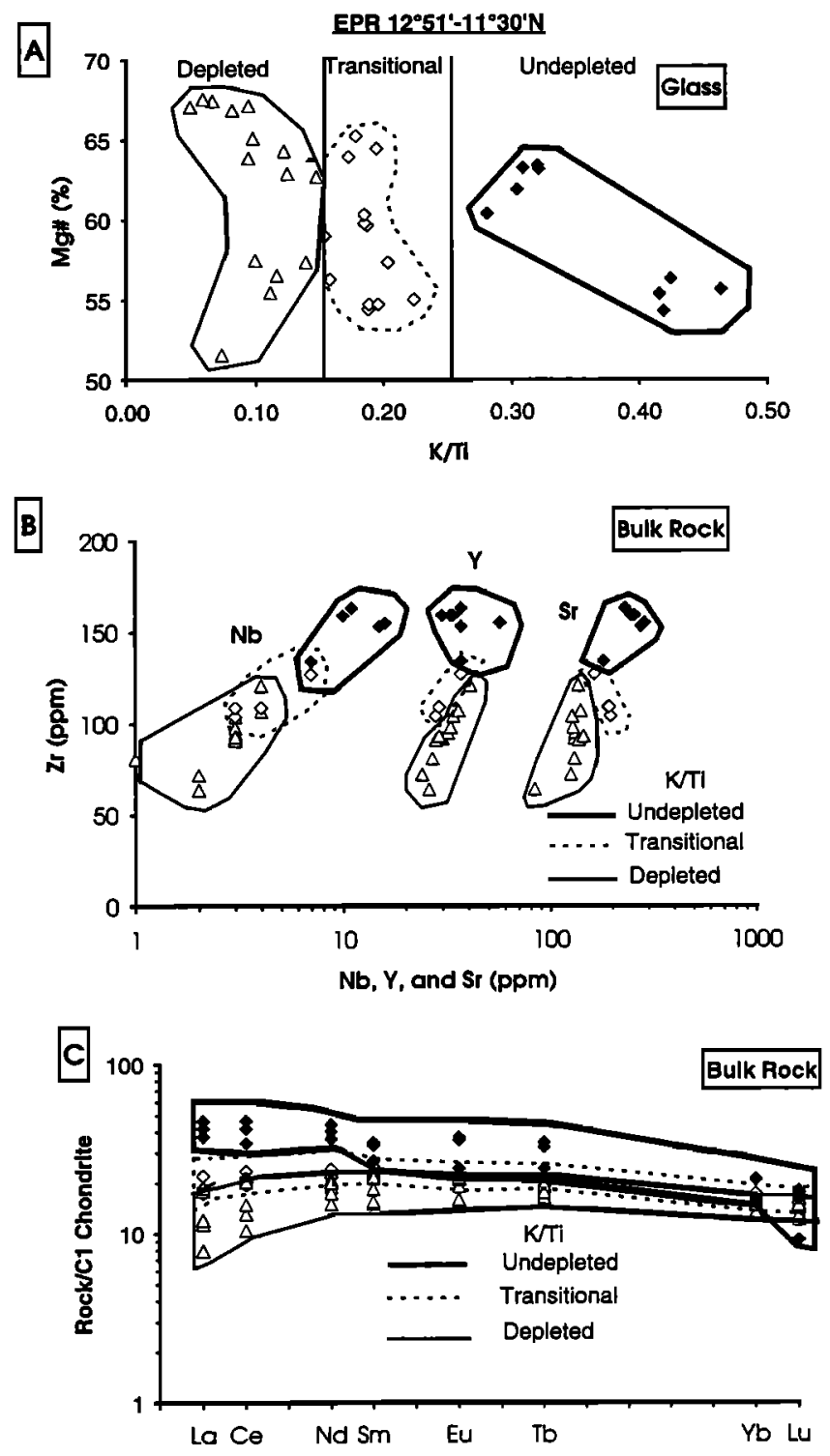

Figure 1. According to their K/Ti ratios, the freshest basaltic glasses recovered from the East Pacific Rise (EPR) axis and from off-axial seamounts near $12^{\circ} 50 \mathrm{~N}$ are classified as undepleted $(\mathrm{K} / \mathrm{Ti}>0.25)$, transitional $(0.15<\mathrm{K} / \mathrm{Ti}<0.25)$, and depleted $(\mathrm{K} / \mathrm{Ti}<0.15)$ basalts. (a) The distribution (glass microprobe data) of their $\mathrm{Mg}_{\#}$ versus $\mathrm{K} / \mathrm{Ti}$ contents indicates 23 main magmatic lineages; the transitional one results possibly from mixing between the two end-members. The classification of the bulk rock data into depleted and enriched compositions is also emphasized by (b) their other incompatible element ratios $(\mathrm{Zr} / \mathrm{Nb}, \mathrm{Zr} / \mathrm{Sr}$, and $\mathrm{Zr} / \mathrm{Y})$ and (c) their normalized rare earth element (REE) patterns. All the data are from Hékinian et al. [1989], and the symbols refer to the K/Ti ratios in glass analyses.

Green, 1980] and that mantle heterogeneities are more readily melted than their surroundings [e.g., Sleep, 1984; Davies and Karsten, 1986]. More recent works based on major element chemistry and referring to laboratory experiments imply nonmodal multiphase melting [Klein and Langmuir, 1987; McKenzie and Bickle, 1988; Niu and Batiza, 1991], and nonmodal incremental melting models were explicitly developed for major elements in peridotites [Kinzler and Grove, 1992a] 


\section{Multi-Stage Melt Extraction Process}

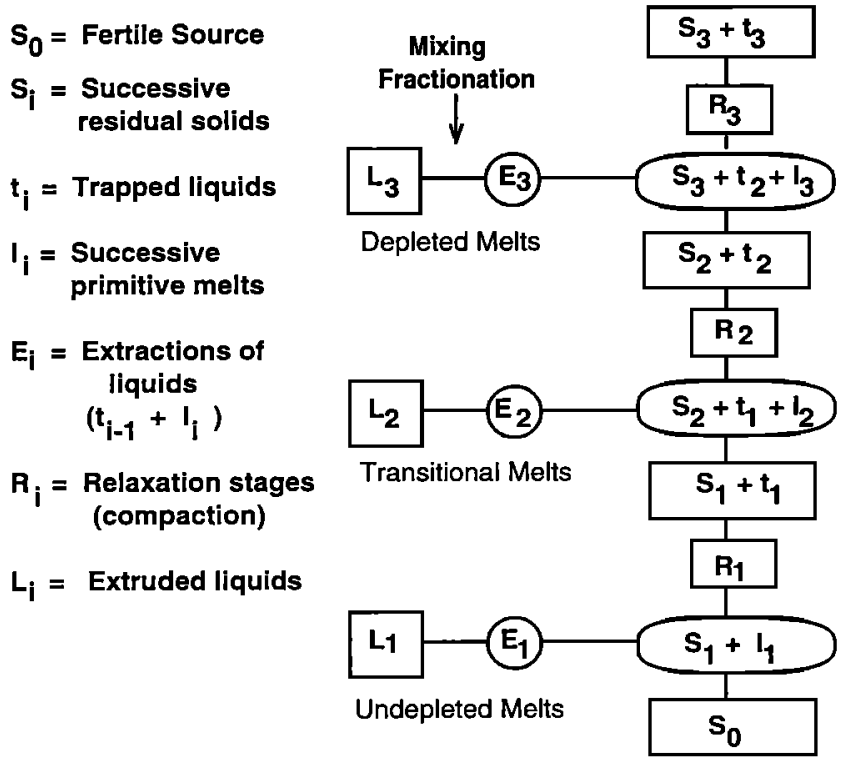

Figure 2. Chronology of the multistage melt extraction model for three melting steps during a single magmatic cycle. $S_{0}$ is the original mantle source, and $S_{1}$ to $S_{3}$ are the successive residual solids; $l_{1}, l_{2}$, and $l_{3}$ are the liquids produced by melting increments at each step; $t_{1}, t_{2}$ and $t_{3}$ are the melt fractions that remain trapped in the solid residuum after each extraction event which expelled the liquids $E_{1}, E_{2}$, and $E_{3} . L_{1}$, $L_{2}$, and $L_{3}$ are the liquids extruded on the ocean floor and are similar to $E_{1}, E_{2}$ and $E_{3}$ if no mixing no fractionation occurred during transport to the surface.

and REEs in mantle clinopyroxene [Johnson at al., 1990]. The basic idea is that during partial melting of a given mantle source, the composition of the melt at a given pressure and temperature is not only related to the total amount of melting, but is an intrinsic property of the mineral constituents of the source (i.e., their respective composition and their relative melting rate). From such a point of view, melting of a homogeneous lherzolitic mantle is also able to produce contrasted melt compositions provided, as proposed by Hékinian et al. [1989], that discontinuous extraction of melt can occur during melting. A recent study of zero-age basalts from the Kolbeinsey ridge (north of Iceland) by Devey et al. [1994] proposes a similar multistage melt extraction model in order to explain large ranges of incompatible element ratios which are not related to variations in radiogenic isotope ratios.

Lherzolites are probably the main component of the primary upper mantle, and their harzburgitic residues after partial melting have undergone a strong depletion, mainly in clinopyroxene. The largest incompatible element concentrations in lherzolites are located in clinopyroxene (plus garnet) and at the grain boundaries. Peridotite melting experiments [Maaloe. 1981] show that melting starts at the maximum grain boundary junctions between olivine, orthopyroxene (opx), clinopyroxene (cpx) and spinel (or garnet), until the clinopyroxene has completely disappeared. If extraction of melt occurs during this early stage of melting, the composition of the magma expelled will be enriched in incompatible elements. When the melting of clinopyroxene reaches completion, the next extracted liquids will be increasingly depleted, until the solidus is sufficiently high to prevent further melting. Melting of $8-20 \%$ in the mantle at 5-16 kbar accounts for the global major element variations in ocean ridge basalts [Klein and Langmuir, 1987; Kinzler and Grove, 1992b]. This implies that clinopyroxene largely predominates as the melting phase during the early stages of the process, but its melting rate, which probably decreases with time, is not entirely constrained. Johnson et al. [1990] used mineral melting proportions corresponding to peritectic melts in four-phase peridotite assemblages for REE modeling. Kinzler and Grove [1992a] estimated the stoichiometric coefficients for mantle melting from experimental data and assumed they were constant over the entire melting range. The stoichiometric coefficients used in the present paper are the mean coefficients calculated for the spinel-lherzolite stability field at various pressures [Kinzler and Grove, 1992a]. However, experiments on dry melting of a clinopyroxenite, or a lherzolite containing isolated lenses of clinopyroxenite, have not yet been done. Also, some variation in the melting curves would appear when melting begins in the spinel-lherzolite field and finishes in the plagioclase-peridotite field, but the transition is unknown. Arguing that the estimates of mean pressure of MORB primary magma generation are relatively shallow (8-15 kbar) and that the aggregate primary magma compositions are not picritic, Kinzler and Grove [1992b] considered that most of the melting occurs in the spinel-stability field.

Experimental melting studies [Waff and Bulau, 1979] and theoretical calculations [Von Bargen and Waff, 1986; Bulau et al., 1979] have shown that the melt forms an interconnected network of channels along triple junctions between grains. According to Maaloe [1981], this melt appears completely interconnected at fractions at least as low as $2 \mathrm{wt} \%$ in some experiments, but the degree of melting required for permeability can reach $10-20 \%$ in others. This range, which was also indicated by some textural features of natural partially molten lherzolite [Maaloe and Printzlau, 1979], was further reduced by other field observations indicating that the maximum amount of trapped liquid in the mantle is less than 7\% [Nicolas, 1986]. From more recent experimental studies, there is a consensus on the upper limit of the permeability threshold which is now less than 2\% [Cooper and Kohlstedt, 1984; Daines and Richter, 1988; Ridley et al., 1990; Cordery and Phipps Morgan, 1992]. As this permeability threshold also depends upon the dihedral angle (i.e., the angle between the surface of two solids in contact with the liquid), the mobility of the liquid should increase in the mantle plume where the partially molten rocks are under tension. From ion microprobe studies of diopside in abyssal peridotite this threshold is believed to be well under $1 \%$ [Johnson et al., 1990].

The major assumption for the multistage melt extraction hypothesis is that the extent of mixing is sufficiently limited to allow the extrusion of melts with distinct magmatic lineages even on the scale of a single seamount. This should imply extraction of melt close to the melting source, rapid percolation to the surface of the Earth, and a period of relaxation between two successive volcanic cycles to prevent the formation of a steady state magma chamber. The amplitude of the gravity anomaly, at least in some places of the ridge system, requires most of the melt to be located deeper than $15 \mathrm{~km}$ [Wilson, 1992]. The depth of generation of primary abyssal tholeiites has been estimated using experimental methods to be about $80 \mathrm{~km}$ [Maaloe and Jakobsson, 1980]. Material upwelling with an initial tempera- 
ture of $1350^{\circ} \mathrm{C}$ meets the solidus at a depth of about $60 \mathrm{~km}$ [McKenzie, 1984]. According to Elthon [1989], the least depleted of abyssal peridotite orthopyroxenes indicate the dominance of melting and primary MORB genesis at pressures greater than $10 \mathrm{kbar}(30 \mathrm{~km})$, and probably greater than $20-25$ kbar (60-70 km). As most of the melting appears to occur in the spinel-stability field, Kinzler and Grove [1992b] suggest that mean pressures greater than $15 \mathrm{kbar}(45 \mathrm{~km})$ are not necessary to explain the major element chemical variations of MORBs. Models assuming an adiabatic ascent of the magma at equilibium with the residuum from about $60 \mathrm{~km}$ depth toward a zone of melt segregation located at about 10-15 km depth [e.g., Nisbet and Fowler, 1978] cannot satisfy the conditions required by our present model because the locus of segregation needs to be proximal to the melting region. Therefore we assume that melting and extraction occurred at several levels between 70 $\mathrm{km}$ and $10 \mathrm{~km}$ depth and that the segregated magma was rapidly expelled toward shallower levels near the mantle-crust transition zone $(<6-8 \mathrm{~km})$, which is consistent with recent polybaric models [Klein and Langmuir, 1987; Kinzler and Grove, 1992b; Langmuir et al., 1992; Forsyth, 1993].

Most of the adiabatic polybaric models of mantle melting are steady state and do not incorporate a time dependent behavior. Using ${ }^{226} \mathrm{Ra}$ data, the time from melting to eruption (and sample collection) is estimated to be $<1000$ years [Rubin and Macdougall, 1988]. This value indicates flow rates of $100 \mathrm{~m} / \mathrm{yr}$ for $100 \mathrm{~km}$ of melt transport and of about $1-10 \mathrm{~m} / \mathrm{yr}$ in a porous medium when the flow is channeled along pressure gradients to the ridge crest [Rubin and Macdougall, 1988]. Structural studies of mantle peridotites [Nicolas, 1986] suggest that melt extraction by dike injection in the brittle zone of the upper mantle is an extremely rapid phenomenon $(5 \mathrm{~cm} / \mathrm{s})$ compared to the rate of the diapiric ascent $(<20 \mathrm{~cm} / \mathrm{yr})$. These findings intrinsically imply that magma supply to the lithosphere is a rather discontinuous process.

Trace element modeling of the multiphase partial melting. Prior to checking the hypothesis of nonmodal incremental melting for trace elements it is necessary to select a suitable mantle source candidate among published data which includes at least major and some trace element analyses, and modal composition. Adequate mineral/liquid partition coefficients are then needed, and the relative proportion of the mineral phases which are melting must be known.

The peridotites recovered from the ocean floor generally represent residual upper mantle material [Dick et al., 1984; Dick, 1989] and are emplaced at shallow levels in the oceanic crust by tectonic processes accompanied by extensive alteration [e.g., Bideau et al., 1991]. The minimum data set required by partial melting models is difficult to find in the literature. Thus published data concerning Hawaiian ultramafic xenoliths [Irving, 1980], xenoliths from the Dreiser Weiher (Westeifel, West Germany) continental volcano [Stosch and Seck, 1980; McDonough et al., 1992], and the Ronda high-temperature peridotites [Frey et al., 1985] are considered here as acceptable candidates for mantle sources. Among these samples, those showing U-shaped REE patterns are disregarded because they are supposed to have been reequilibrated with rising melts or metasomatic fluids in the upper levels of the asthenosphere [Stosch and Seck, 1980]. The spinel lherzolite $\mathrm{Ib} / 8$ from Dreiser Wheiher (Table 1) containing about $21 \%$ clinopyroxene is finally selected for our purpose because it represents the most fertile peridotite and has a close composition to that expected for a MORB primary upper mantle [McDonough et al., 1992].
Table 1. Composition of the Ultramafic Sources

\begin{tabular}{|c|c|c|c|c|c|}
\hline & $\mathrm{Ib} / \mathbf{8}$ & Lb75 & SC73-2P & $\mathrm{R} 255$ & $R^{*}=15 / 85$ \\
\hline & \multicolumn{5}{|c|}{ Modal, \% } \\
\hline Olivine & 0.49 & 0.55 & 0.02 & 0.71 & 0.60 \\
\hline Orthopyroxene & 0.29 & 0.25 & 0.00 & 0.20 & 0.17 \\
\hline Clinopyroxene & 0.21 & 0.18 & 0.90 & 0.07 & 0.20 \\
\hline \multirow[t]{2}{*}{ Spinel } & 0.01 & 0.02 & 0.08 & 0.02 & 0.03 \\
\hline & \multicolumn{5}{|c|}{ Trace Elements, ppm } \\
\hline $\mathbf{L a}$ & 0.88 & - & 3.46 & 0.30 & 0.77 \\
\hline $\mathrm{Ce}$ & 2.20 & 0.92 & 12.20 & 0.78 & 2.49 \\
\hline Pr & 0.25 & - & - & - & - \\
\hline Nd & 1.59 & 0.82 & 0.00 & 0.69 & 0.59 \\
\hline Sm & 0.47 & 0.33 & 4.13 & 0.26 & 0.84 \\
\hline $\mathrm{Eu}$ & 0.18 & 0.13 & 1.44 & 0.12 & 0.32 \\
\hline Gd & 0.61 & - & - & - & - \\
\hline $\mathrm{Tb}$ & 0.11 & - & 0.88 & 0.07 & 0.19 \\
\hline Dy & 0.74 & 0.61 & - & - & - \\
\hline Ho & 0.16 & - & - & - & - \\
\hline Er & - & 0.40 & - & - & - \\
\hline $\mathrm{Tm}$ & 0.07 & - & - & - & - \\
\hline $\mathrm{Yb}$ & 0.49 & 0.40 & 1.96 & 0.38 & 0.62 \\
\hline $\mathrm{Lu}$ & 0.08 & - & 0.31 & 0.07 & 0.10 \\
\hline $\mathrm{Ni}$ & 1590 & & 680 & 2190 & 1964 \\
\hline$Z x$ & & & 66 & 6 & 15 \\
\hline $\mathrm{Y}$ & & & 25 & 3 & 6 \\
\hline
\end{tabular}

Spinel-lherzolite Ib/8 is from McDonough et al. [1992], Spinellherzolite Lb75 is from Johnson et al. [1990], spinel-clinopyronite is from Irving [1980], and spinel-lherzolite R255 is from Frey et al. $[1985] . R^{*}$ is $15 \%(\mathrm{SC73}-2 \mathrm{P})+85 \%(\mathrm{R} 255)$.

The composition of an alpine type peridotite published by Loubet et al. [1975], and used by Johnson et al. [1990] for REE modeling, is also considered here for comparison and will be referred to hereafter as sample Lb75 (Table 1). Unfortunately, the trace element data on these samples are limited to REEs, and as far as $\mathrm{Zr}$ and $\mathrm{Y}$ are concerned, we used the concentration from another source made up of a mixure of $15 \%$ spinel clinopyroxenite SP73-2P [Irving, 1980] and 85\% spinel lherzolite R255 [Frey et al., 1985]. This choice is partly justified because the mantle at EPR $13^{\circ} \mathrm{N}$ is believed to be composite. However, it is somewhat arbitrary because sample R255 is already residual (7\% cpx) and the REE pattern of sample SP732P presents a negative anomaly in light rare earth elements (LREEs). The melting curves calculated for a simple nonmodal fractional melting model are plotted together with the basalts from the East Pacific Rise axis near $13^{\circ} \mathrm{N}$ in a $\mathrm{Ce}_{N}$ versus $(\mathrm{Ce} / \mathrm{Yb})_{N}$ diagram (Figure $3 \mathrm{a}$ ), and similar results are obtained for La/Sm (not shown here). All the selected ultramafics are too enriched in LREEs to represent suitable sources, but the lherzolites $1 / \mathrm{b} 8$ and Lb75 (Figures 3a, 4a, and 4c), with a melting curve plotting below the data, are the best candidates of the selection. Indeed, the sampled MORB glasses contain 9.56 to 
A
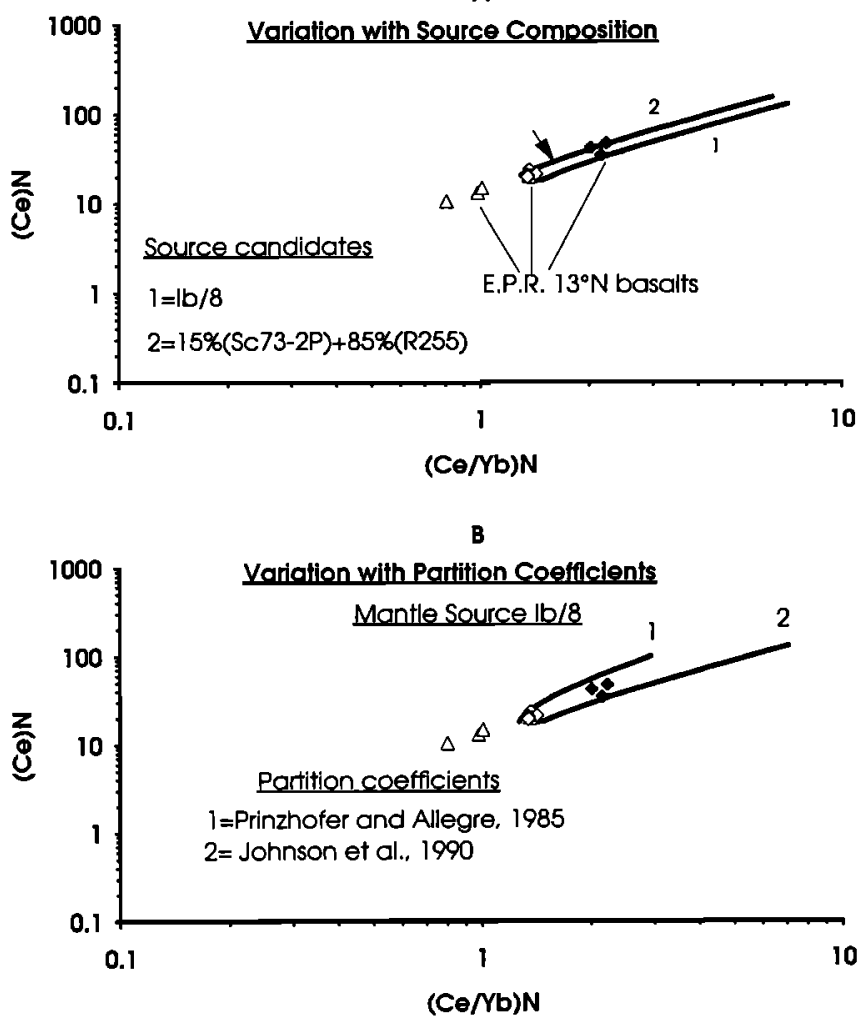

c

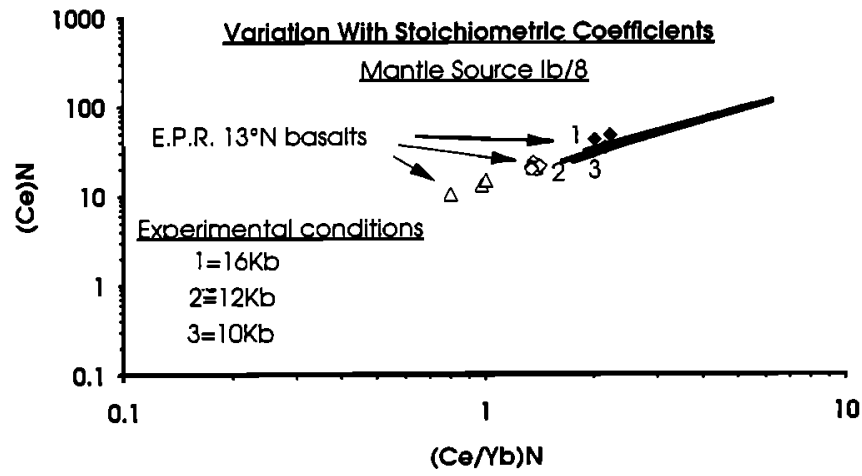

Figure 3. Calculated compositions of the aggregate melts issued from $1-20 \%$ fractional melting (Raleigh fractionation) in $\mathrm{Ce}_{N}$ versus $(\mathrm{Ce} / \mathrm{Yb})_{N}$ diagrams. (a) Influence of the mantle source composition (partition coefficients are from Johnson et al. [1990]; stoichiometric coefficients are the mean coefficients estimated by Kinzler and Grove [1992a] for spinel-lherzolites). (b) Influence of the choice of partition coefficients on the melting curve. The source used is the fertile spinel-lherzolite xenolith $\mathrm{I} / \mathrm{b} 8$ from the Dreiser Weiher volcano $[\mathrm{McD}$ Donough et al., 1992]. (c) Influence of stoichiometric coefficients in the spinel-lherzolite field for different experimental conditions [Kinzler and Grove, 1992a]. The composition of the basalt from the East Pacific Rise (EPR) near $13^{\circ} \mathrm{N}$ [Hekinian et al., 1989] is represented for comparison (same symbols as in Figure la). The compositions are normalized to the $\mathrm{C} 1$ chondrite [Sun and McDonough, 1989].

$6.63 \% \mathrm{MgO}$ (mean value of $8.01+/-0.92 \% \mathrm{MgO}$ ), suggesting they suffered limited extent ( 3 to $18 \%$ ) of low-pressure crystal fractionation [Hékinian et al., 1989].

The choice of a given set of partition coefficients (Table 2) can severely influence the position of the curves in the diagrams (Figure $3 \mathrm{~b}$ ). When available, the partition coefficients selected on the basis of severe criteria by Johnson et al. [1990] are favored. Testing the influence of the choice of stoichiometric coefficients does not modify significantly the shape and the position of the melting curve on the plot (Figure 3c). However, it is assumed at first approximation that both the partition and stoichiometric coefficients remained constant over the entire range of melting. This assumption is probably unrealistic because the source composition should change during incremental melting with discontinuous extraction, and because melting should occur at different levels in the mantle under variable thermodynamic conditions. Also, the maximum amount of melting used in the calculations is limited to less than about $20 \%$ because the stoichiometric coefficients are not available for clinopyroxene-out conditions.

The next step was to choose an adequate model for generating the parental melts of the EPR $13^{\circ} \mathrm{N}$ basalts. A recent ion microprobe study of REE content in clinopyroxene of abyssal peridotites [Johnson et al., 1990] suggests that partial melting is close to fractional melting. The authors favored a model of incremental near-fractional melting which does not significantly modify the melting curves for the aggregate melt compositions but implies less extensive depletion of the mantle residue and is more consistent with their observations. For this simple model to be realistic in terms of MORB composition, the melts which segregate from the melting region have to aggregate at shallow levels before extrusion. Thus drastic temporal or spatial variations in the melting conditions, or aggregations in shallow-level isolated pockets, are required in order to explain the diversity of basalts observed on a single seamount. Small unconnected magma pockets directly reflecting the composition of deep-seated mantle heterogeneities are also invoked in a model by Natland [1989].

Another possibility is a multistage melt extraction model [Hékinian et al., 1989; Devey et al., 1994] which is not incompatible with Natland's model but is also able to produce some basalt diversity from melting of an homogeneous lherzolitic source. The conceptual model of multiphase melting [Hékinian et al., 1989; Kinzler and Grove, 1992a] implies several stages of batch melting with incomplete magma withdrawal between each step (see appendix). A simple preliminary model consisting of three steps of batch melting and extraction gave reliable results to explain the distribution of the MORBs sampled near $13^{\circ} \mathrm{N}$ on the EPR with less than $15 \%$ total melting (about 18 vol \%). However, in order to fit the most enriched compositions, the permeability threshold, which represents the amount of melt produced during each batch melting step, has to be close to $7 \mathrm{wt} \%$. This is not consistent with the results of Johnson et al. [1990] and the most recent works on melt migration processes (see previous section) which consider that segregation occurs at very low melt concentration $(<<1 \%)$.

An alternative solution is to consider that migration in the melting zone occurs at low $(<1 \%)$ degrees of melting and that some amount of melt accumulation (a few percent) occurs at the top or above the melting region. At first sight, this hypothesis seems incompatible with melt migration at low extent of melting $(<1 \%$ ). However, mantle porosity variations are clearly considered in conceptual models where magma is accumulated and interstratified in the refractory mantle by compaction [e.g., Maaloe, 1981], and it is implicitly assumed in polybaric geochemical models dealing with the composition of aggregate primary magma produced by various degrees of fractional or near-fractional melting [Johnson et al., 1990; Kinzler 

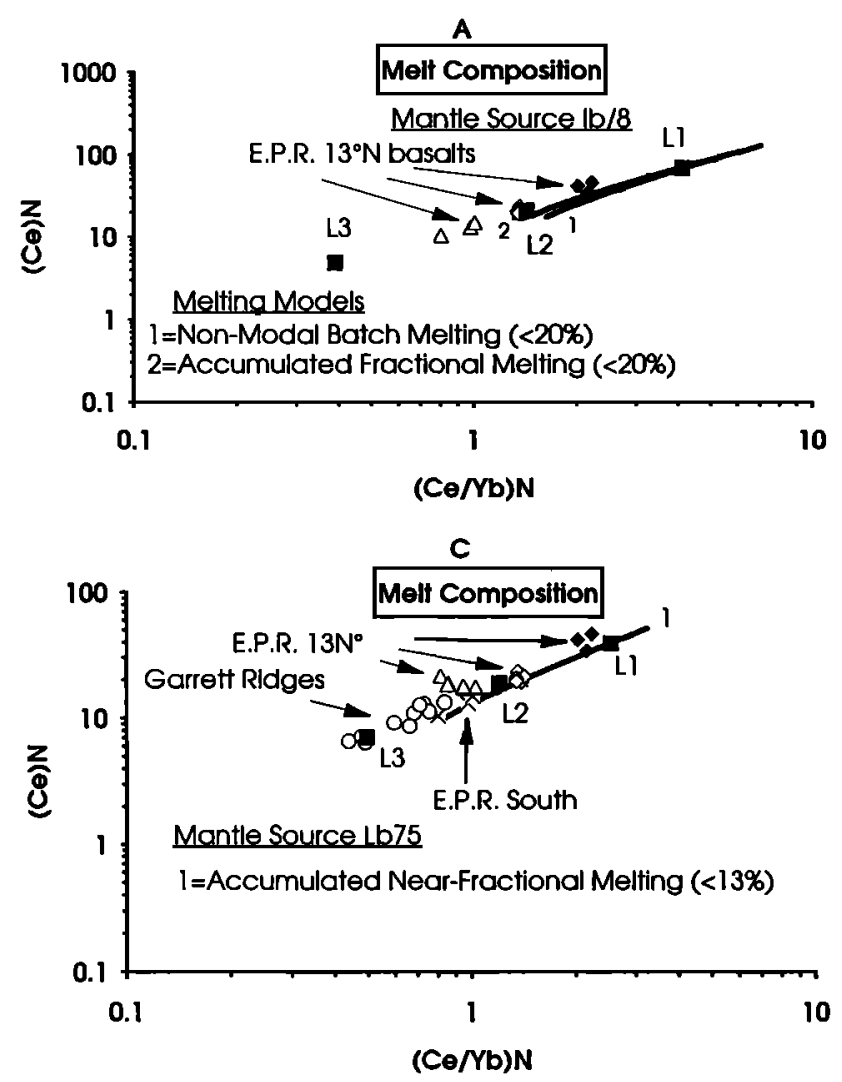
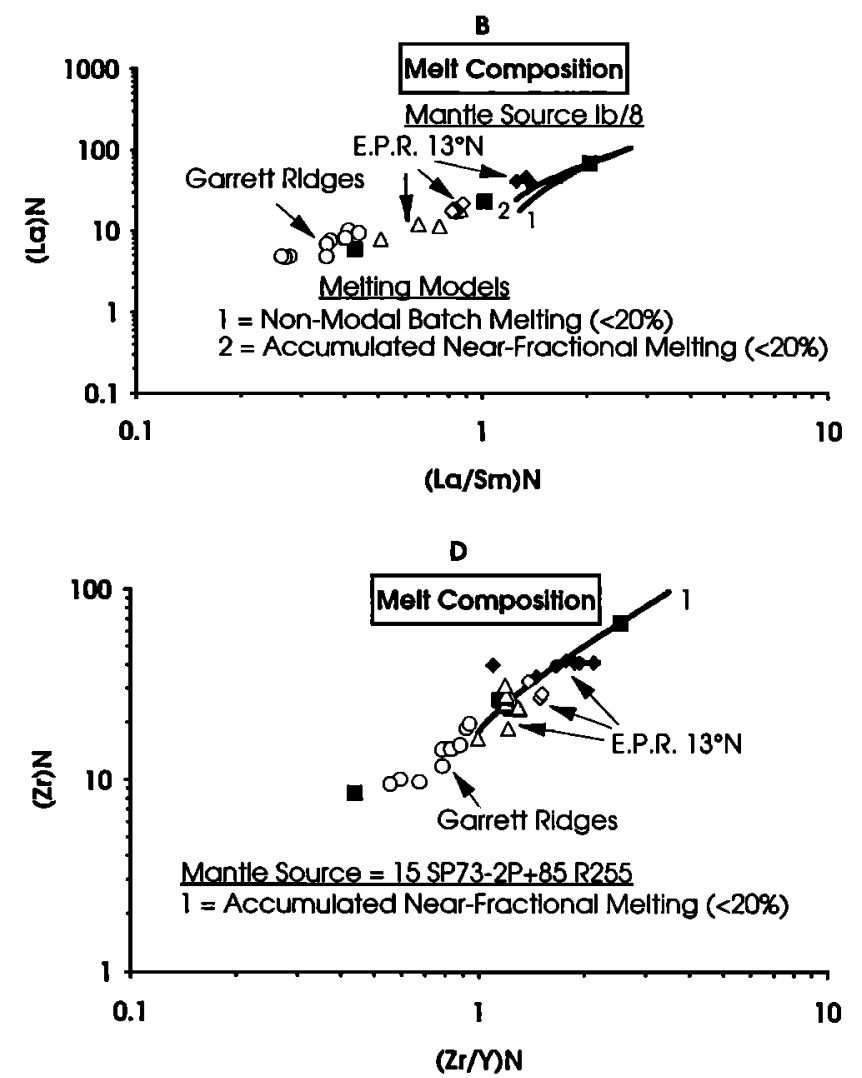

Figure 4. Composition of the primary magmas after partial melting of a lherzolitic mantle and three steps of melt accumulation-extraction. The curves are calculated for batch melting, fractional melting and near-fractional melting. (a) $\mathrm{Ce}_{N}$ versus $(\mathrm{Ce} / \mathrm{Yb})_{N}$ diagram. The composition of the basalt from the East Pacific Rise (EPR) near $13^{\circ} \mathrm{N}$ is represented for comparison (see legend in Figure 3). The open squares represent the composition of the liquids $\left(L_{1}, L_{2}\right.$ and $\left.L_{3}\right)$ at each stage. (b) LaN versus $(\mathrm{La} / \mathrm{Sm})_{N}$ diagram. The field of the recent intratransform volcanics (open circles) of Garrett fracture zone (EPR, $1^{\circ} \mathrm{S}$ ) are added for comparison. Garrett data [Hekinian et al., this issue] are restricted to the samples recovered from oblique volcanic ridges within the transform valley. In Figures 4a and 4b the source is the spinel lherzolite $\mathrm{I} / \mathrm{b} 8$ [McDonough et al., 1992]. The permeability threshold of the accumulation zone (PTAZ) is $<5 \%$, and the total extent of melting (TEM) is $<13 \%$. (c) Ce $N$ versus $(\mathrm{Ce} / \mathrm{Yb})_{N}$ diagram (PTAZ $<2.5 \%$ and TEM $<8 \%$ ). The source is the alpine type peridotite Lb75 (see text) used by Johnson et al. [1990]. Data from the EPR south of the Garrett transform [Hekinian et al., this issue] are added (crosses). (d) $\mathrm{Zr}_{N}$ versus $(\mathrm{Zr} / \mathrm{Y})_{N}$ diagram (PTAZ $<5 \%$ and $\mathrm{TEM}<13 \%$ ). The source (see text) is a mixture of 15\% spinel-clinopyroxenite [Irving, 1980] and 85\% spinel lherzolite [Frey et al., 1985].

and Grove, 1992a, b]. The melt fractions are supposed to accumulate somewhere in the ascending column but not necessarily in a shallow level magma chamber. The existence of an accumulation region located in the mantle is also intrinsic to physical models exploring buoyancy-driven segregation of light fluid from a deformable matrix [e.g., Richter and McKenzie, 1984; Turcotte, 1987; Spiegelman, 1993] or nonhydrostatic stress variations in a convective mantle [e.g., Rabinowicz et al., 1987; Phipps Morgan, 1987]. Indeed, viscosity and density variations in a buoyant compacting and decompacting partially molten mantle and an increase of tensional stresses should change the size of the dihedral angles and induce recrystallization of the deformable matrix. Both these conditions are known to modify the melt topology in experimental melting of lherzolites [e.g., Bussod and Christie, 1991; Waff and Faul, 1992]. The presence of a high-porosity decompacting layer at the boundary of the melting region is also explicitly studied in a physical model by Sparks and Parmentier [1991].

Thus we assume that the melt accumulates in a refractory mantle (no more melting) somewhere above the melting region and ceases to react with the solid matrix. Then, the composition of the melts and solids resulting from two steps and three steps of extraction are calculated (see appendix). The two-step experiment can reproduce the required compositions for less than $15 \%$ total melting of source $\mathrm{I} / \mathrm{b} 8$, but an unlikely permeability threshold of about $10 \%$ in the accumulation region is needed to obtain the enriched end-member. The three-step hypothesis (about 5\% accumulation at each step) gives similar values of $\mathrm{Ce} / \mathrm{Yb}$ (Figure 4a) and $\mathrm{La} / \mathrm{Sm}$ (Figure $4 \mathrm{~b}$ ) ratios for the depleted end-member with less than $13 \%$ (about $15 \mathrm{vol} \%$ ) total melting of source I/b8. However, it cannot account for the EMORB compositions at EPR $13^{\circ} \mathrm{N}$, because the enriched endmember is too enriched. The three-step calculations applied to source Lb75 (Figure 4c), which is lower in total REE content (and particularly in LREEs) than $\mathrm{I} / \mathrm{b} 8$ (Table 1), improve the results for the E-MORBs with a permeability threshold of less than $2.5 \%$ in the accumulation region. This $2.5 \%$ of melt represents the amount of melt segregated from the melting region 
Table 2. Partition Coefficients

\begin{tabular}{|c|c|c|c|c|c|c|c|c|c|c|c|c|}
\hline Phase & $\mathrm{Zr}^{*}$ & $\mathrm{Y}^{*}$ & $\mathrm{La}^{\dagger}$ & $\mathrm{Ce}^{\dagger}$ & Ndt & $\mathrm{Sm}{ }^{\dagger}$ & $\mathrm{Eu}^{\dagger}$ & Gd $\dagger$ & Dy ${ }^{\dagger}$ & $\mathrm{Er}^{\dagger}$ & $\mathrm{Yb}{ }^{\dagger}$ & Lut \\
\hline$D(\mathrm{O} / \mathrm{L})$ & 0.01 & 0.01 & 0.00044 & $\begin{array}{c}0.0003 \\
{[0.001]}\end{array}$ & $\begin{array}{c}0.0002 \\
{[0.002]}\end{array}$ & $\begin{array}{c}0.00018 \\
{[0.003]}\end{array}$ & $\begin{array}{c}0.0002 \\
{[0.003]}\end{array}$ & 0.00025 & $\begin{array}{l}0.0007 \\
{[0.012]}\end{array}$ & $\begin{array}{l}0.00174 \\
{[0.025]}\end{array}$ & $\begin{array}{l}0.00522 \\
{[0.059]}\end{array}$ & 0.00852 \\
\hline$D(\mathrm{Opx} / \mathrm{L})$ & 0.02 & 0.2 & 0.0012 & $\begin{array}{l}0.00162 \\
{[0.005]}\end{array}$ & $\begin{array}{l}0.0028 \\
{[0.01]}\end{array}$ & $\begin{array}{l}0.0054 \\
{[0.02]}\end{array}$ & $\begin{array}{l}0.0078 \\
{[0.03]}\end{array}$ & 0.0111 & $\begin{array}{c}0.01975 \\
{[0.045]}\end{array}$ & $\begin{array}{l}0.0392 \\
{[0.06]}\end{array}$ & $\begin{array}{c}0.06 \\
{[0.075]}\end{array}$ & 0.0703 \\
\hline$D(\mathrm{Cpx} / \mathrm{L})$ & 0.107 & 0.5 & 0.12 & $\begin{array}{l}0.15 \\
{[0.1]}\end{array}$ & $\begin{array}{c}0.2 \\
{[0.19]}\end{array}$ & $\begin{array}{l}0.24 \\
{[0.3]}\end{array}$ & $\begin{array}{c}0.25 \\
{[0.42]}\end{array}$ & 0.263 & $\begin{array}{l}0.29 \\
{[0.5]}\end{array}$ & $\begin{array}{c}0.294 \\
{[0.51]}\end{array}$ & $\begin{array}{c}0.3 \\
{[0.5]}\end{array}$ & 0.31 \\
\hline$D(\mathrm{Sp} / \mathrm{L})$ & & & 0.0002 & $\begin{array}{c}0.0002 \\
{[0.0005]}\end{array}$ & {$[0.0008]$} & $\begin{array}{c}0.0001 \\
{[0.0009]}\end{array}$ & {$[0.0009]$} & 0.263 & {$[0.0015]$} & {$[0.003]$} & $\begin{array}{c}0.0012 \\
{[0.0045]}\end{array}$ & 0.0004 \\
\hline
\end{tabular}

Numbers in brackets are from Johnson et al. [1990].

* Hékinian et al. [1991].

$\dagger$ Prinzhofer and Allègre [1985].

and aggregated in the accumulation zone before each extraction event, minus the amount of trapped liquids left in the accumulation region by prior extraction (see appendix). Therefore this percentage refers to the initial melting solid, and it is assumed to approximate the permeability threshold of the refractory mantle in the accumulation zone. Although the calculated composition of the depleted end-member after only $8 \%$ (about 9 vol $\%$ ) total melting shows too much depletion to fit the N-MORBs of the EPR $13^{\circ} \mathrm{N}$ data, it is compatible with the composition of the very depleted rocks recovered from the inner volcanic ridges of the Garrett transform (EPR near $13^{\circ} \mathrm{S}$ ). The $\mathrm{Zr}$ versus $\mathrm{Zr} / \mathrm{Y}$ diagram constructed using the composite source $(15 \%$ SP73-2P and 85\% R255) gives similar results (Figure 4d), but the melting curve plots within the MORBs data indicating that the selected sources are too enriched in total incompatible element content.

The REE patterns obtained after each stage of melting of the lherzolite Lb75 give a reasonable fit with the observed data (Figure 5), provided they are primitive basalts. However, these basalts underwent some (3-18\%) differentiation [Hékinian et al., 1989, 1992], and their real source should be slightly lower in total REE content. The results obtained for the solid residues give intermediate values between equilibrium nonmodal batch melting and fractional melting (Figures $6 \mathrm{a}$ and $6 \mathrm{~b}$ ). This trend is close to near fractional melting, but with lower depletion of the final residue. The available data for normal (non U-shaped) lherzolites plot in the upper part of the curves, suggesting along with the REE spectrum (Figure 7) that the permeability threshold in the accumulation zone $(<2.5 \%)$ and the total amount of melting ( $<8 \%$ ) corresponding to Lb75 are more reasonable values than found with $\mathrm{I} / \mathrm{b} 8(<5 \%$ and $<13 \%$, respectively). The same types of calculations, when applied to the composite source issued from the mixture of $15 \%$ clinopyroxenite SP73-2P and $85 \%$ R255 therzolite, give rise to a strong depletion in the LREE pattern (not shown here) which does not fit the observed data. This depletion is inherited from the clinopyroxenite LREE content (Table 1) confirming that sample SP73-2P is not a good example of enriched component forming the composite mantle in the area of EPR $12^{\circ} 52 \mathrm{~N}$.

The three-step melt extraction model provides a plausible range of incompatible element variation for MORB composition at EPR $13^{\circ} \mathrm{N}$ if the observed distribution results from increasing amounts of mixing in a shallow level magma chamber. Such a magma reservoir might form during upwelling of the early producted E-MORBs and disappear after the end of a

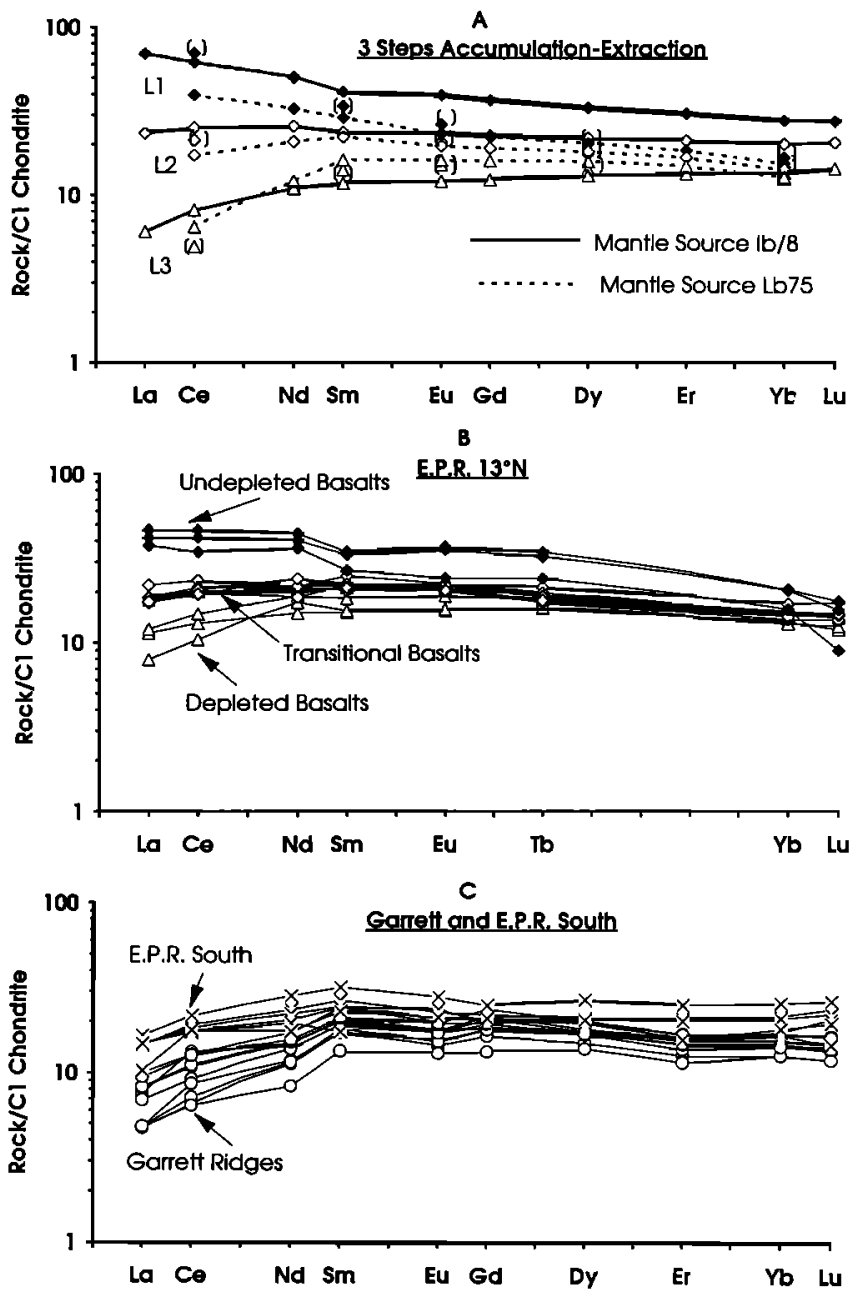

Figure 5. Chondrite-normalized rare earth element (REE) patterns (Cl [Sun and McDonough, 1989] ) of the melts: (a) after three successive steps of melting/accumulation/extraction of a lherzolitic mantle source. The sources are the spinel lherzolites I/b8 and Lb75 (see text and Figure 4). The partition coefficients for $\mathrm{I} / \mathrm{b8}$ are from Prinzhofer and Allègre [1985] and from Johnson et al. [1990] (symbols within parentheses). The values used for Lb75 are from Johnson et al. [1990]. (b) Comparison with East Pacific Rise (EPR) $13^{\circ} \mathrm{N}$ data [Hekinian et al., 1989], and (c) data from EPR south of Garrett transform and from the Garrett intratransform ridges [Hekinian et al., this issue]. Symbols are the same as in Figure 4. 

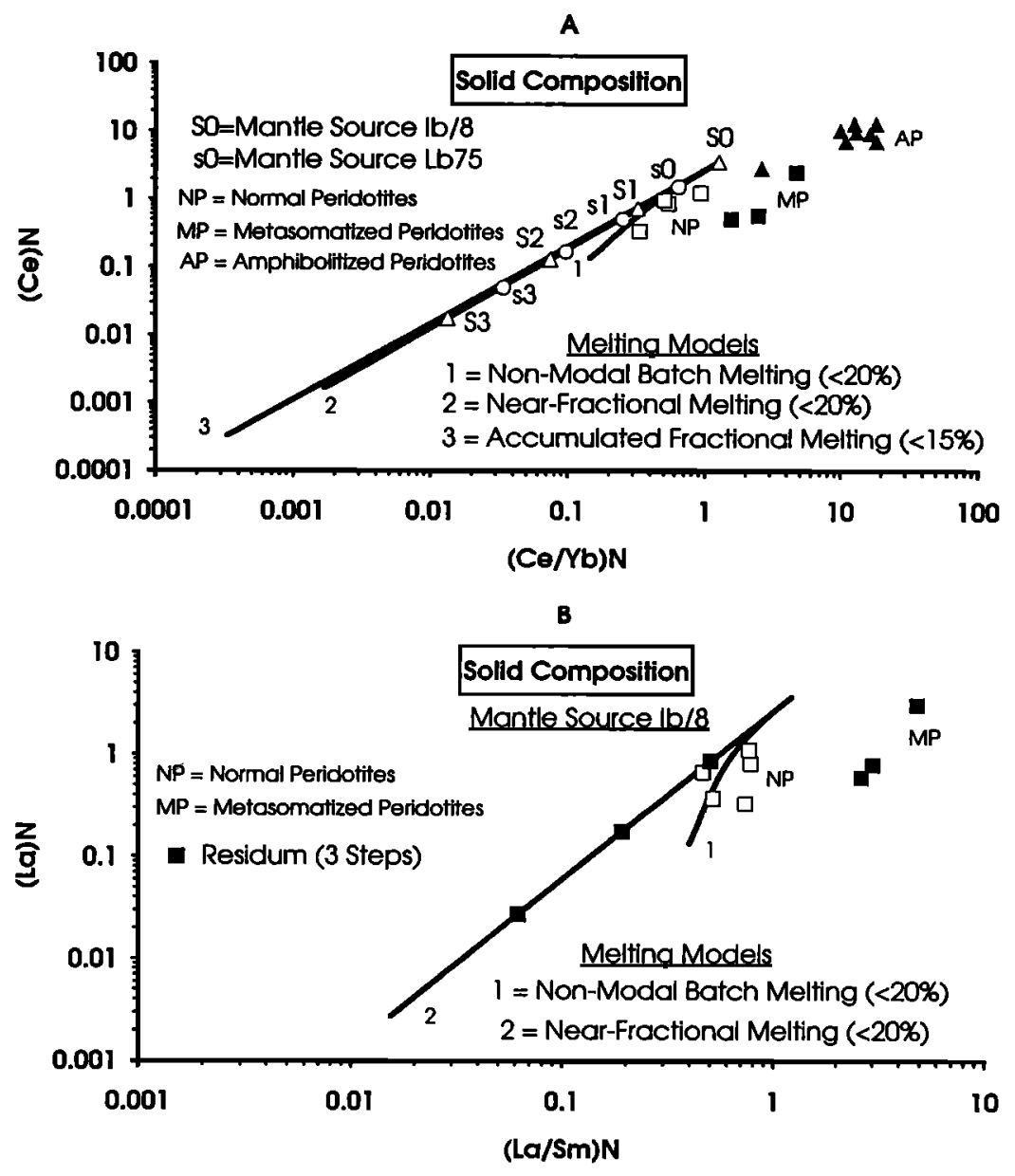

Figure 6. (a) $\mathrm{Ce}_{N}$ versus $(\mathrm{Ce} / \mathrm{Yb})_{N}$ and (b) $\mathrm{La}_{N}$ vs $(\mathrm{La} / \mathrm{Sm})_{N}$ diagrams of the residual solid compositions during three steps of melting/accumulation/extraction of a lherzolitic mantle. The melting conditions and the references for source compositions are indicated in text and Figures 4 and 5 . The curves are calculated for nonmodal batch melting, fractional melting and near-fractional melting. For comparison, the composition of the normal (non Ushaped rare earth element pattern), the metasomatized (U-shaped) and the amphibole-bearing peridotite xenoliths from the Dreiser Weiher volcano [Stosch and Seck, 1980; McDonough et al., 1992] are also plotted.

magmatic cycle. As proposed by Hékinian et al. [this issue], the very depleted intratransform basalts from Garrett should predominate if a large amount of E-MORBs freeze in the upper mantle/lower crust transition zone without reaching the surface. The thermal boundary effect of the transform fault would delay the formation of a sizable magmatic reservoir, but progressive reheating of the feeding conduit by successive melt injections would finally permit regular extrusion of late-produced depleted melts. Of course, another possibility is the lateral drift of residual mantle in the transform area after previous melting at the intersection with the ridge [Hékinian et al., this issue]. A multistage melt extraction process should result in some kind of rhythmicity in lateral zoning of surface lava composition when small-scale distribution of the enriched component in the composite mantle remains regular during several magmatic cycles. However, the expected rhythmicity should be partly or completely obliterated when the injection rate of enriched mantle blobs in the melting area is becoming chaotic and/or when the width of the active volcanic zone is broad or variable.

\section{Discontinuities in Magma Supply: \\ "Melting Pulse" Hypothesis}

The current models dealing with partial melting in the vicinity of the mid-ocean ridge crests are steady state and consider passive upwelling of an heterogeneous mantle source and nearcontinuous magma supply to the lithosphere [McKenzie and Bickle, 1988; Plank and Landmuir, 1992; Forsyth, 1993]. This kind of models can explain most of the along strike and lateral compositional variations in basalt chemistry, provided that some variation in depth and amount of total melting can occur from place to place in relation to spreading rate, ridge segmentation, or distance of young off-axis seamount from the ridge crest. An additional degree of complexity is obtained by introducing chaotic distribution of small-scale heterogeneities in the mantle [e.g., Natland, 1989] and variations in shallow level magmatic processes, such as fractional crystallization and mixing [e.g., Christie and Sinton, 1981; Hey et al., 1989]. However, these steady state models do not perfectly explain the zero-age diversity of basalt when the presence of a narrow, thin lens of melt is suggested by geophysical experiments, as is the case at the EPR axis near $13^{\circ} \mathrm{N}$ [e.g., Caress et al., 1992].

To adopt the hypothesis of multistage melt extraction is to assume the existence of discontinuities in the magma supply. Several physical models of melt extraction beneath spreading centers imply a time dependent behavior of magma supply [Sotin and Parmentier, 1989; Spiegelman, 1993]. Other studies on the structure of the EPR [Choukroune et al., 1984; Hékinian et al., 1985], and on the spatial and temporal evolution of axial 


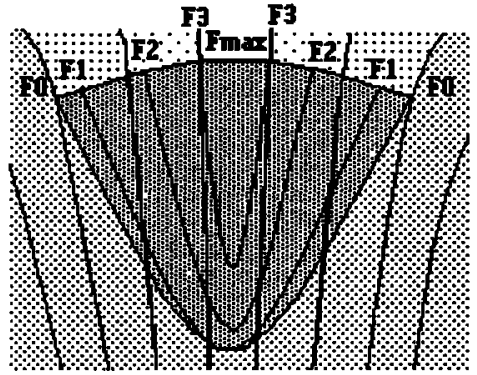

A

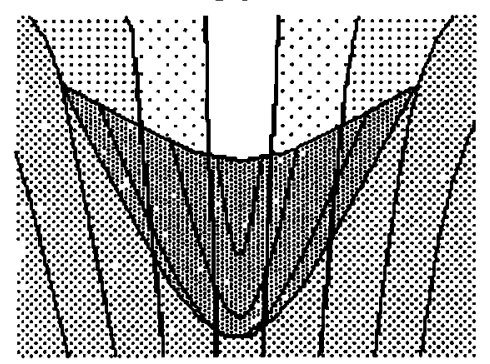

B

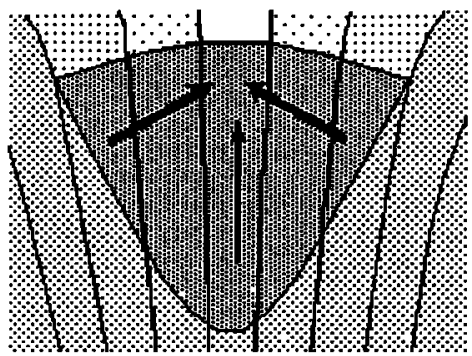

C

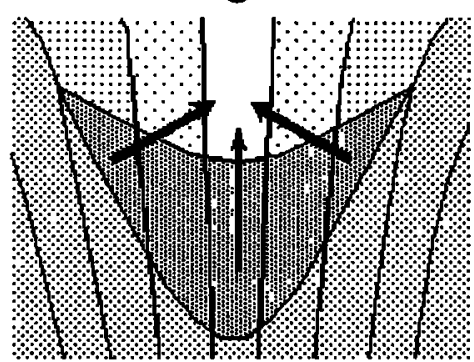

D

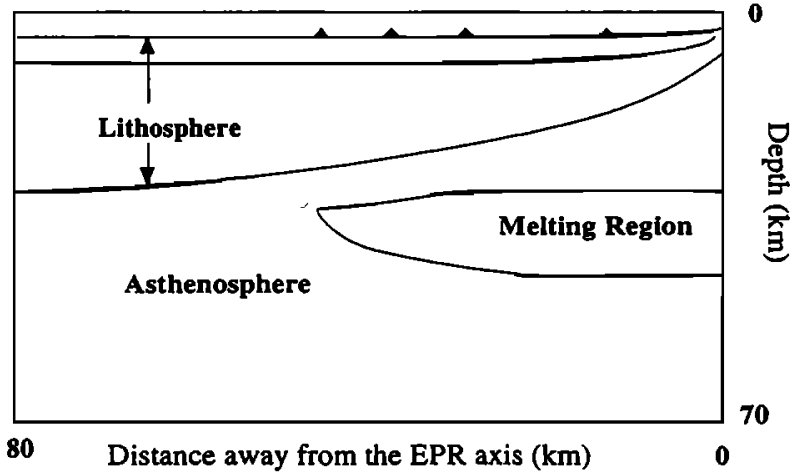

E

Figure 7. A idealized two-dimensional shape of the melting zone. (a) The basal envelope is interrupted at $F_{0}$ because it is assumed that the change of the thermal structure (slope of the isotherms) as the result of nearadiabatic polybaric upwelling of the mantle diapir will prevent the solidus from beeing reached beyond this region. The curves inside the melting zone represent isomelting curves which can be solidi of successive mantle residues. The roof of the melting zone is not a solidus but the integration of the points $F_{0}$ to $F_{\max }$ where no more melting can occur for respective composition of the solid residue. Above this roof, the mantle is considered as refractory. (b-d) Depending on the shape adopted for the roof of the melting zone, the magma tends to accumulate in a still-melting mantle or in a refractory mantle. (e) The shape of the melting zone (slightly modified) as imagined by Niu and Batiza [1991].

morphology [Lewis, 1979; Gente et al., 1984; Kappel and Ryan., 1986; Pockalny et al., 1988], also suggest that volcanic activity is episodic. However, there is a controversy concerning the tectonic versus volcanic origin of off-axis half-graben structures based on simple bathymetric considerations. A highresolution survey of the EPR from $12^{\circ} 50 \mathrm{~N}$ to $15^{\circ} 10 \mathrm{~N}$ using the SeaMARC II sonar system did not permit to clarify this problem [Edwards et al., 1991]. A study of the systematics of normal faulting and the topographic roughness of mid-ocean ridge flanks by Malinverno and Cowie [1993] concludes that normal faulting can explain all the observed topographic roughness, but some differences existing between predictions and observations are likely to be due to other processes (e.g., volcanism). The variation of intensity of volcanic, tectonic, and hydrothermal activity observed during submersible operations [e.g., Gente et al., 1984] or when using the near-bottom ARGO imag- ing system [Haymon et al., 1991] are also suggestive of axial volcanism episodicity, but these small-scale features are most likely regulated by shallow level magmatic processes.

The observed periodicity of volcanism introduces the notion of cyclicity in the magmatic activity. The hypothesis of multistage melt extraction aslo implies a cyclicity of magma production if repeated several times in similar conditions. Petrological [Hékinian and Walker, 1987] and chemical [Reynolds et al., 1992] zonations have been observed on the Mid-Atlantic Ridge (MAR) and EPR, respectively, but the recurrence of basaltic compositional zonations which should reflect the cyclicity of the magmatic activity at depth has not been observed in the field. This is partly because most of the detailed work was carried out at zero age on the ridge axis and partly because thermal boundary effects and chaotic distribution of fertile components in the mantle source along with mixing processes should 
tend to complicate the pattern of basalt distribution from place to place. Before exploring the consequences of the magmatic cyclicity hypothesis and the possibilities of demonstrating its existence through basalt chemical studies, it is necessary to constrain the concept of a discontinuous melt extraction and to relate it to some physical processes.

Individualized mantle diapirs. One explanation for magma supply discontinuities is the instability of the deepseated processes related to asthenospheric convection. There is a lot of evidence of mantle instability over the world oceans (fluctuations in spreading rates, change in directions of spreading, jumps of ridge axis, etc.). However, these events occur sporadically over long periods of time (10-100 m.y. and more) and cannot account for the regular variations in the occurrence of the volcanism on shorter timescales. Another explanation might be the fluctuation of the convecting mantle velocity or the discontinuous injection of fertile mantle blobs or diapirs from depth. Slow spreading ridge segments in the Atlantic are characterized by central elongated highs related to negative residual gravity anomalies [e.g., Kuo and Forsyth, 1988; Lin et al., 1990]. These anomalies, interpreted as upwellings of individualized mantle diapirs, are considered as a possible origin for the local trends of major element chemical variations encountered on slow spreading ridges [Niu and Batiza, 1993]. These structures are not observed on the EPR because mantle upwelling is probably more regular beneath a fast spreading ridge than beneath the MAR [e.g., Lin and Phipps Morgan, 1992].

Melt segregation processes. There is a consensus that migrating magma is focused in a very narrow zone when ascending to the surface [e.g., Phipps Morgan, 1987; Wilson, 1992]. Numerous processes have been invoked in order to explain high-velocity migration of magma through the mantle matrix. Several of these processes might be operating successively at different levels of the upwelling mantle. Among these, buoyancy forces [Sleep, 1974; Turcotte and Ahern, 1978; Sotin and Parmentier, 1989] and high-temperature anisotropic permeability resulting from low lateral pressure gradients could initiate segregation, giving rise to the formation of subvertical flow banding [Phipps Morgan, 1987; Scott and Stevenson, 1989]. Pressure-driven fluid fractures and/or propagating tension gashes [Nicolas and Jackson, 1982; Nicolas, 1986] could also increase the efficiency of melt extraction in the ductile part of the mantle diapir above the melting zone. Finally, dike propagation is probably the most efficient and the main transport process in the brittle lithosphere. These processes acting successively should accelerate the upward segregation of the melt and might partly explain the formation of discret magma batches, leading to the observed diversity of basalt extrusions. Also, they can account for distinctive magma compositions of seamounts at some distance of the ridge axis (see next sections).

Geophysical models and ${ }^{230} \mathrm{Th} /{ }^{238} \mathrm{U}$ data suggest that melting occurs within a broad zone extending up to $50-100 \mathrm{~km}$ on both sides of the ridge axis and then focuses in narrow column [Reid and Jackson, 1981; McKenzie, 1985; Phipps Morgan, 1987; Cordery and Phipps Morgan, 1993]. This structure (Figure 7) implies that lateral migration of melt occurs in the melting zone. Recent studies of melting peridotites converge on the idea that melt is interconnected at very small degrees of melting ( $<1-2 \%)$, and that capillarity forces [Riley et al., 1990] and porous flow in a deformable matrix [McKenzie, 1984;
Richter and McKenzie, 1984; Scott and Stevenson, 1986] are the most likely phenomena for melt collection at depth. However, this should be a rather continuous process. Instead, if magma accumulates somewhere at the top of the melting zone before extraction [Maaloe, 1981; Hékinian et al., 1989], then gravitational compaction [Sleep, 1974; Maaloe, 1981; McKenzie, 1984; Richter and McKenzie, 1984] could combine with buoyancy forces for initiating rapid segregation of the melt. Gravitational compaction is probably not important in a mantle melting by decompression [Ribe, 1985], but it might induce small discontinuities in magma supply.

Shape and structure of the melting zone. There are several physical models of the shape of melting zone available in literature, among which two extreme cases are discussed by McKenzie and Bickle [1988]. One case [Oxburgh, 1980] is rejected by McKenzie and Bickle [1988] because it implies the existence of a strong lateral temperature gradient in the upwelling mantle, which is difficult to explain. The second case is based on the concept of the polybaric adiabatic ascent of the mantle beneath ridge axis, which is largely accepted today by the scientific community [e.g., Cordery and Phipps Morgan, 1992]. However, these are extreme conditions which consider that heat transfer in the upwelling mantle is only the result of convection [McKenzie and Bickle, 1988], and this model does not account for the entire geochemical observations [Niu and Batiza, 1991]. If one assumes a small deviation from ideality with small amount of conductive cooling in the upper part of the asthenosphere, then the actual temperature gradient below the ridge is slightly greater (cooler) than adiabatic, and a small lateral temperature gradient will affect the pattern of the isotherms and the depth of initial melting [Niu and Batiza, 1991]. As the bottom of the melting zone is represented by the solidus of the fertile primary mantle, its shape is expected to be a concave surface; the curvature of this boundary should be accentuated by the existence of a small lateral pressure gradient where the convective asthenosphere is under tension. In order to magnify the expected zonation of melt distribution at the periphery of the melting zone, its bottom curvature has been highly exaggerated in Figures $7 \mathrm{a}$ to $7 \mathrm{~d}$. A more realistic model should probably flatten at the bottom of the axial area as represented in Figure 7e. Also, this area in Figures $7 \mathrm{a}$ and $7 \mathrm{~b}$ is strickly representing not a region where the mantle is melting continuously but the potential location of melting which can occupy different levels during a complete magmatic cycle. However, this region is also occupied nearly continuously by small amounts $(<1 \%)$ of melts slowly migrating toward the accumulation region. The depth of this latter region might also vary (decrease) between two steps. The shape of the roof, whether it is concave or convex is also important because the melt which is forced to accumulate in the axial region [Wilson, 1992] might concentrate in a refractory mantle in one case and in the potentially melting mantle in the other (Figures 7c and 7d). Anyway, the most important point is that slight lateral temperature and stress gradients will induce the zoning of the melting region. The minimum amount of melting necessary to initiate melt migration in the melting zone should increase in the most external layers, and this minimum might be higher than the melting potential. Of course, the relative thickness of this layer $\left(F_{0}\right.$ to $\left.F_{1}\right)$ is actually exagerated in Figure 7 , and the field $\left(\mathrm{F}_{2}-\mathrm{F}_{3}\right)$ of near-fractional melting is probably representing the largest portion of the melting region. In any case, no extraction is possible in these extreme conditions, and the liquid produced 


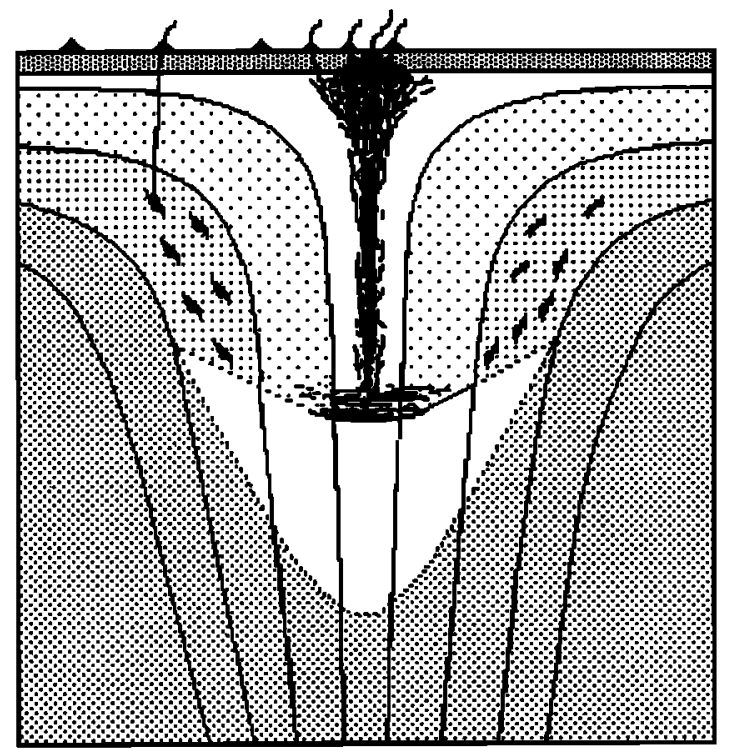

Figure 8. A possible explanation for enriched compositions of the lava erupted on seamount built on an old lithosphere at some distance of the ridge crest. The amount of melt produced in the external part of the melting zone might have never reached the local permeability threshold and should remain entrapped in residual solid during upwelling.

might remain entrapped in the residuum and ascend to upper levels of the asthenosphere at the same speed as the residue (Figure 8). This magma, potentially enriched in incompatible elements, can be liberated by intraplate tectonics (reactivation of faulting) at some distance away from the ridge crest, either because it has never crossed back to its solidus (off-axis seamounts) or because it has been partially remelted (intraplate volcanoes). In the case of an heterogeneous mantle, this magma should acquire a different isotopic signature than the axial melts. As in the Natland [1989] model, this structure can explain some extent of mixing in the central part of the melting zone and an increased compositional diversity at the boundaries, particularly when the pattern of the mantle heterogeneities is chaotic.

Instability of the melting zone (the "pulse" theory). Assuming a constant velocity of the convecting mantle and a nearadiabatic polybaric upwelling of the diapir, strengthening of tension and subsequent pressure release during the amagmatic phase (no extraction) will lead the fertile primary mantle to reach its solidus at a critical depth beneath the ridge crest. Moreover, if this increase in tension is rapid, it should create a disequilibrium in the ascending column and a temperature gradient which could be slightly lower than adiabatic (heat release) and initiate melting. This sudden heat supply can be entirely or partly absorbed by melting, progressively restoring the normal thermal gradient. From this point of the ascending diapir, the melting zone under increasing tension will expand laterally and deepen, until enough melt is aggregated in the accumulation zone to initiate segregation (Figure 9a). As discussed in a previous section, this accumulation zone might result from increasing tension at shallower depth, enhancing deformation and decompaction of the refractory mantle and allowing provisional retention of small amounts of magma by increasing porosity and changing melt topology. Then, the rapid migration of the melt toward shallow levels should allow relaxation of the tension field, contraction of the melting zone and compaction of the accumulation area (Figure 9b). When repeated several times during a magmatic cycle (Figures 9b-9e), this process will result in successive pulses, acting as a pump (Figure 10). This occurs when the supply of fertile mantle in the melting area is sufficiently slow when compared to the melt migration velocity (Figures 9a-9f). At the start of the magmatic period, the increase in tension is sufficient for the deep-seated fertile mantle to melt. After extraction, the field will increase again, but the solidus of the residual is reached at lower depth than previously. When the mantle affected by the first melting cycle is completely dry (refractory mantle), new fertile mantle rising from the asthenosphere abysses has to be influenced by melting to initiate a new cycle. This period of time corresponds the amagmatic period (no melt extraction), or the period of recharge of the melting zone by fertile primary source (Figure 10). The first melts extruded at the begining of a magmatic cycle will be enriched in incompatible elements, and the next parental melts will be increasingly depleted until the residual mantle "dries out" (refractory mantle including minor amounts of trapped liquid). This is probably the most attractive model for initiating multiphase melting, discontinuous extraction, large-scale volcanic periodicity separated by periods of quiescence, and thermal fluctuations in the lithosphere.

The intralithospheric processes. The rapid and discontinuous ascent of the magma should profoundly modify the thermal structure of the axial lithosphere through time by reheating periodically the feeding conduit. During high magmatic supply, the axial column remains hot enough to allow the formation of long-lived and large-size magma chambers in the lower crust, where efficient mixing takes place [Sinton and Detrick, 1992]. During accumulation stages or between two magmatic cycles the upper part of the conduit is rapidly cooled by thermal conduction and hydrothermal convection (Figure 9f). Thus the size of the shallow level magma reservoir or mush zone [Sinton and Detrick, 1992] will successively contract and expand through time (Figures 9 and 10). In absence of magma supply, at the end of a magmatic cycle, the extent of fractionation and/or in situ fractionation [Langmuir, 1989] could be sufficient to provide highly differentiated lavas (i.e., ferro-basalts). Convective streams in the magma reservoir and opening of fissures in response to spreading stresses are secondary processes which would regulate the rate of magma extrusions during magmatic cycles (Figure 10).

\section{Consequences and Limitations of the "Pulse" Theory: Global Petrogenetic Applications}

The magmatic cyclicity and the thermal regime of the lithosphere which are inherent to the dynamics of the melting zone as derived from the "pulse" theory depend on the velocity of the convective mantle and thus on the spreading rate. They should have a direct influence on the petrogenetic processes which occur in the ocean crust, but visualizing their effects on basalt compositional distribution over the world ocean ridges is not straightforward if thermal boundary effects or chaotic occurrence of small-scale mantle heterogeneities affects the pattern of the expected petrological zonation. If there are some places where the pattern of mantle heterogeneity is maintained sufficiently regular for a long enough period of time (several magmatic cycles), the only factor to consider is the cooling rate of the lithosphere. The tip of ridge propagators which combines both the effects of thermal boundaries and spreading rate vari- 


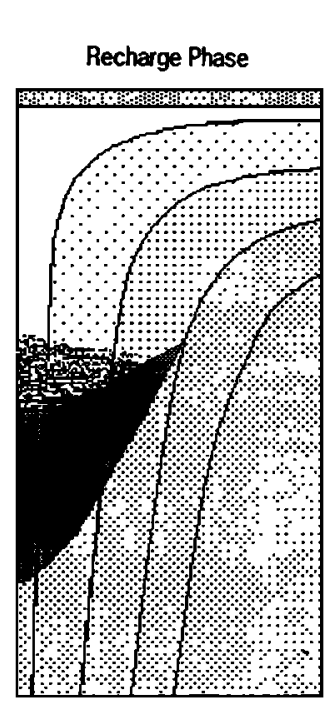

a

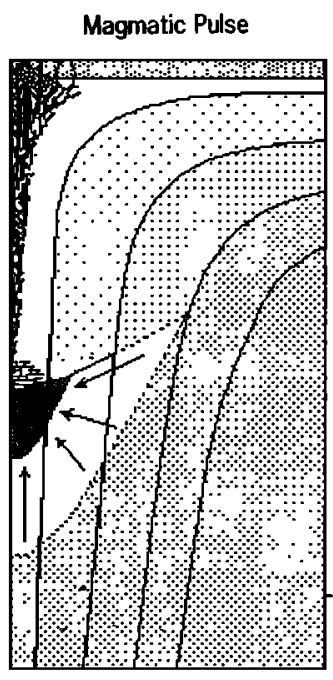

d

\section{Volcanic cycle}

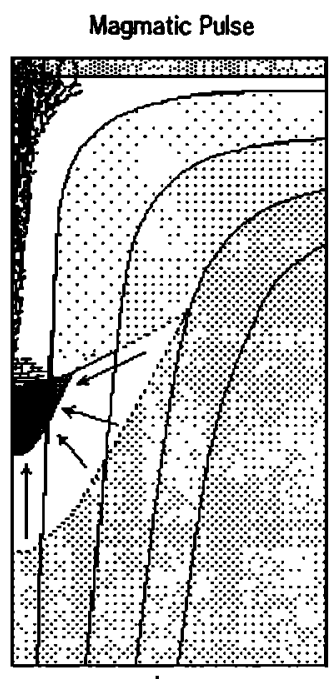

b

Relaxation Time

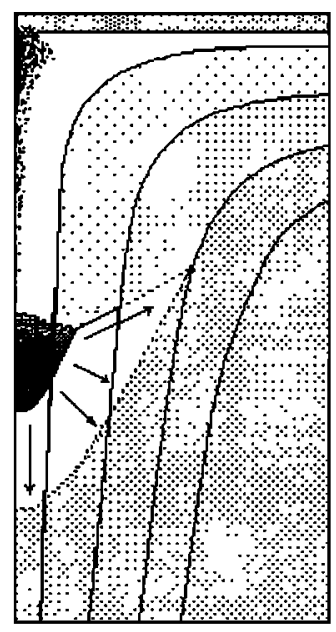

e

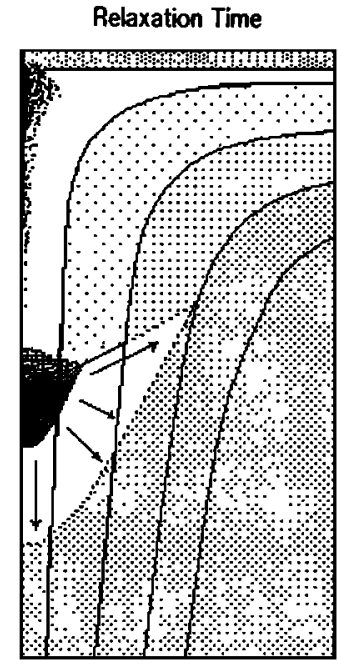

c

End of volcanic phase

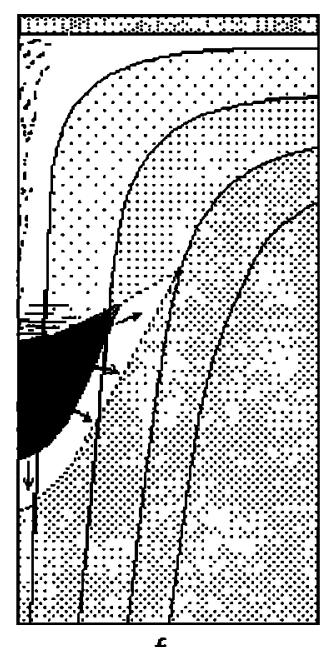

f

Figure 9. Idealized dynamics of the melting zone as a consequence of the multistage melting/accumulation/extraction model at the axis of a spreading ridge with marked amagnatic period between two magmatic cycles. (a) Pressure drop and increasing tensional stresses initiate melting of the deep-seated enriched mantle and progressive growth of the melting zone. The melt produced accumulates nearly continuously above the melting zone. (b) When the permeability threshold of the accumulation region is reached, this enriched melt is rapidly expelled toward the lithosphere. The resulting release of tension forces the melting zone to contract (magmatic pulse). (c) Then, the melting zone expands again during restoration of the tensional regime, but at lower depth, affecting residual mantle and preventing contamination by deep-seated enriched sources. (d) When enough melt is aggregated in the accumulation zone, a new extraction occurs. (e) Then the tensional regime increases again, but the mantle is now refractory. (f) The fertile primary mantle rising from asthenosphere abysses is affected by incipient melting. During this amagmatic phase, the absence of magma supply allows the shallowest melt conduits to cool and/or to freeze. The melting zone expands at depth, until enough primary mantle has penetrated its domain (recharge phase) to restore the initial conditions (Figure a).

ations on limited distances is probably the key to this discussion.

\section{Effects of Ridge Propagation}

On the basis of studies of propagator tips, Christie and Sinton [1981] have proposed idealized cooling paths for crustal magma bodies as a function of time and temperature. These regions are characterized by along strike chemical variations of the zero-age basalts and particularly by a drastic change in $\mathrm{FeO}^{*} / \mathrm{MgO}, \mathrm{TiO}_{2}$, and $\mathrm{Zr}$ contents near the tip [Christie and Sinton, 1981; Hey et al., 1989]. These observations are interpreted in terms of increasing mixing with the distance from the propagator tip and high degrees of fractionation near the tip [e.g., Hey et al., 1989]. Moreover, the drastic increase in con- 


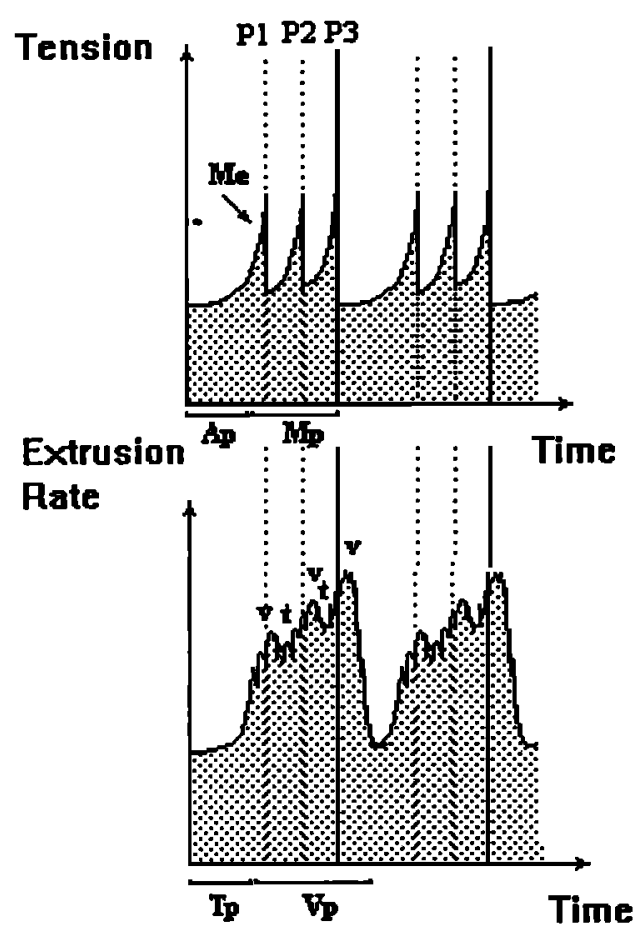

Figure 10. Consequences of the magmatic pulse hypothesis on shallow level processes. $P_{1}, P_{2}$, and $P_{3}$ are successive magmatic pulses related to rapid melt extractions followed by relaxation of the tensional regime in the melting zone. $M_{e}$ is magmatic event in the accumulation zone. $A_{p}$ is amagmatic period (recharge of the melting zone by fertile primary mantle). $M_{p}$ is magmatic period (multistage discharge of the accumulation zone). $T_{p}$ is tectonic period (low constructional activity on the ridge). $V_{p}$ is volcanic period (high constructional activity). Secondary small-scale volcano-tectonic events ( $v$ and $t)$ are regulated by contraction and extension in small-sized shallow level nonsteady state magmatic reservoirs.

trast of basalt composition in the vicinity of the tip is consistent with the existence of a multistage melt extraction process at depth. At the extreme tip, where no magma chamber is developed, part of the melts produced are rapidly quenched in the very lower crust or in the upper mantle and primitive depleted basalts are common [Christie and Sinton, 1981; Hey et al., 1989]. It is likely that the early intrusion of enriched melts in the upper asthenosphere and/or the lower lithosphere could sufficiently heat the upwelling column to allow a further extrusion of a very depleted material. Rapid cooling should enhance high crystal nucleation rates and limited crystal settling, resulting in the production of viscous porphyritic lavas such as those observed by submersible at the tip of the Cocos-Nazca propagator [Hékinian et al., 1993]. An attempt to generalize this concept is proposed in Figure 11, where the relationships between the magmatic processes and the variations of the average cooling rate of the lithosphere, as inferred from previous studies on the compositional pattern of propagators [e.g., Hey et al., 1989] and from the preceding sections, are summarized. This qualitative scheme (Figure 11) considers the complex but more general notion of cooling rate rather than spreading rate, distance from thermal boundaries, periodicity of magma supply, or any combination of these factors, and supports the following detailed discussions.

\section{Influence of the Spreading Rate}

The broad relationship existing between spreading rates and mid-ocean ridge basalt composition also suggests that composition is partly controlled by variations of the thermal budget at the ridge axes [Bass, 1971; Schreidegger, 1973; Morel and Hekinian, 1980; Holness and Richter, 1989; Niu and Batiza, 1993]. The relationship between the melting pulses and the magma supply frequency as illustrated in Figure 10, which seems suitable for EPR $13^{\circ} \mathrm{N}$, has to be adapted to variable conditions of spreading (Figure 12). Indeed, ultrafast spreading rates should enhance high frequency of magma supply, stability of the thermal structure, and formation of long-lived to steady state magma chambers where efficient mixing can occur (Figure 11). However, a high extent of fractionation at the end of magmatic cycles should allow extrusions of highly differentiated lavas (i.e., ferro-basalts and andesites). On the other hand, intermediate to slow spreading rates will accentuate the contrast between volcanically and tectonically active zones (Figure 12).

Morphological variations along the axis of the slow spreading Mid-Atlantic Ridge (MAR) have been interpreted in terms of construction-dominated and stretching-dominated spreadings [Karson et al., 1987], suggesting that lateral compositional zonations at the axis of the ridge [Hékinian and Walker, 1987] are time dependent rather than distance dependent from the center of a steady state magma chamber. The thermal conditions at slow spreading ridges are also comparable to those encountered at the extreme tip of propagating ridges, and the compositional variations are expected to be similar for the same mantle source (Figure 11). Furthermore, in the case of extremely slow spreading conditions, the lava erupted will be highly phyric, poorly fractionated depleted basalts. These hypotheses are supported by many published works recording primitive phyric basalts on the Atlantic and Indian mid-ocean ridges [Arcyana, 1976; Melson et al., 1976; Bryan and Moore, 1977; Hékinian and Walker, 1987; Niu and Batiza, 1993]. The first lava erupted should be very viscous, carrying a large amount of early formed olivine crystals (picritic basalts). Then, the persistence of small magma pockets in the lower crust will allow olivine sedimentation and plagioclase flotation. The next erupted lavas will be phyric-plagioclase basalts at the beginning and progressively aphyric basalts at the end, if the melt is accumulated on top of a crystal-melt mush [Sinton and Detrick, 1992]. Here also, some extent of fractionation and or in situ fractionation [Langmuir, 1989] might provide occasionally differentiated lavas (i.e., depleted ferro-basalts). This could explain the petrological zoning reported on the EPR at $21^{\circ} \mathrm{N}$ and on the MAR at $36^{\circ} 50^{\prime} \mathrm{N}$ [Bryan et al., 1979; Hékinian and Walker, 1987]. These explanations are consistent with the observation by Niu and Batiza [1993] that the EPR basalts follow a global compositional trend as defined by Klein and Langmuir [1987, 1989] and that MAR basalts are mainly following local trends. Indeed, the contrasted compositions found locally on slow spreading ridge segments and attributed by $\mathrm{Niu}$ and $\mathrm{Ba}$ titza [1993] to the distribution of enriched and depleted melts in distinct upwelling diapirs might also be produced by a model of multistage melt extraction from the melting region, or both.

During long-lasting amagmatic periods (ultraslow spreading rate), the cooling of the upper mantle and crust is more efficient, and the first enriched segregated magmas may never reach the surface (Figure 11); instead, they may form dikes and sills and/or part of the magmatic impregnations in the upper 


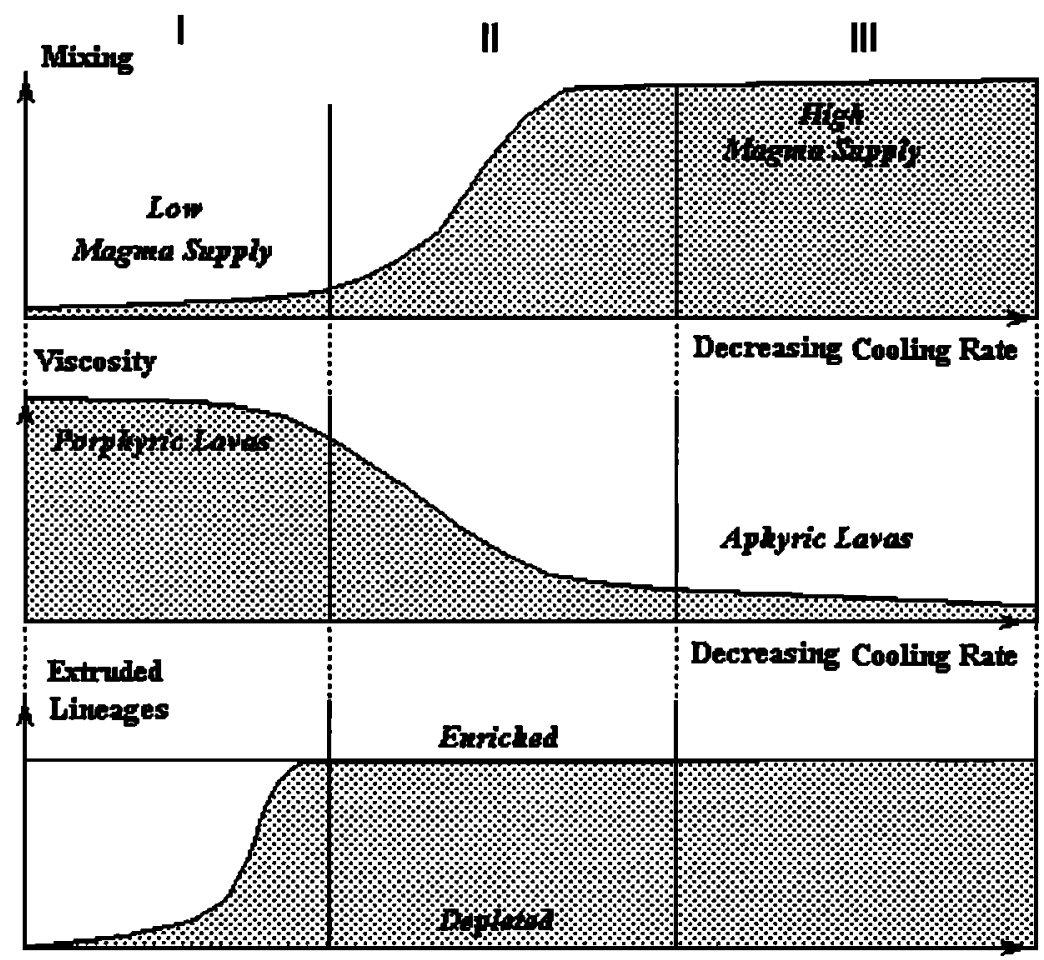

Decreasing Cooling Rate

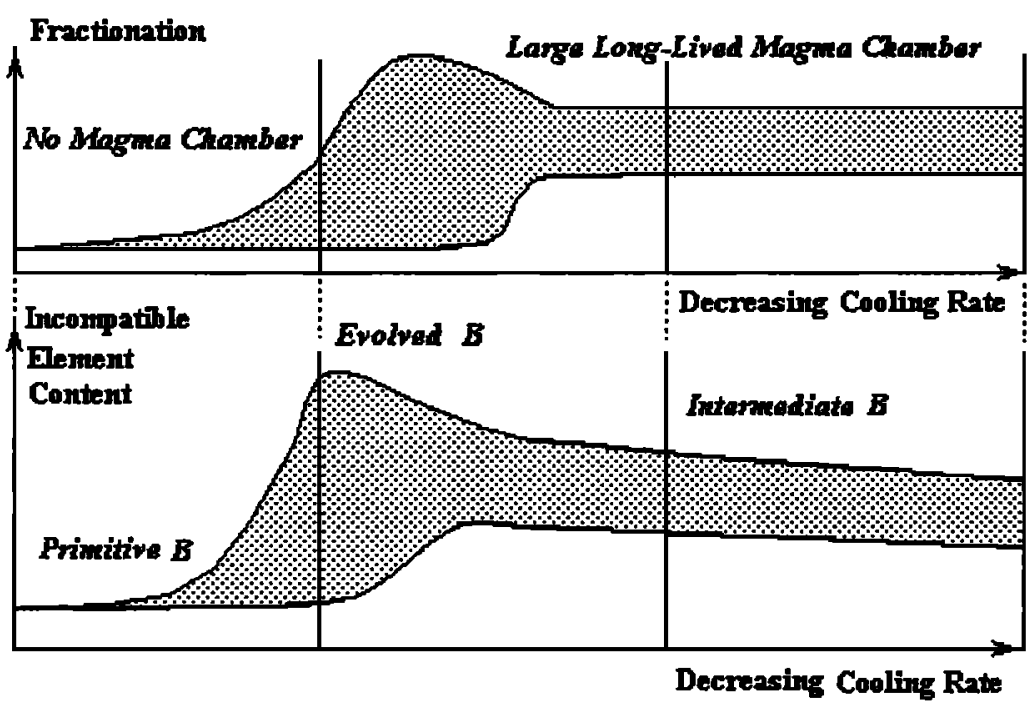

Figure 11. Summary of possible magmatic processes involved in the generation of small-scale MORB heterogeneities, as a function of the average cooling rate of mid-ocean ridges. Process I: High cooling rates correspond to low magma supply and absence of a magma chamber. This prevents extensive mixing and fractionation. The basalts extruded are primitive depleted N-MORBs when the cooling rate is sufficient to freeze the early produced E-MORBs before reaching the surface. In addition, the increased viscosity due to rapid cooling will favor the extrusion of porphyritic lavas (high nucleation rate, low crystal settling). Process II: Intermediate cooling rates correspond to moderate magma supply and presence of a small short-lived magma chambers. The limited frequency of replenishments allows limited extent of mixing and parental melt composition ranging from depleted N-MORBs to E-MORBs. However, high crystal fractionation will produce ferro-basalts. Viscosity variations should permit extrusion of slightly porphyritic to aphyric lavas. Process III: At low cooling rates, high magma supply and formation of a large-sized, long-lived magma chamber permits extensive mixing, but moderate fractionation. Restricted range of chemical variations, low viscosity, and high crystal settling allows preferential extrusion of aphyric N-MORBs.

mantle. During spreading and stretching of the lithosphere [Karson et al., 1987], the lack of magma supply may be partially compensated for by uplifts of serpentinized bodies. The intrusions of serpentinized peridotites in the axial valley of the ridge are a common feature of the MAR [e.g., Cannat et al., 1992; Cannat, 1993]. During the recharge of the melting zone by fertile primary mantle (Figures 11 and 12), these crustal serpentinite intrusions could delay the begining of the next 

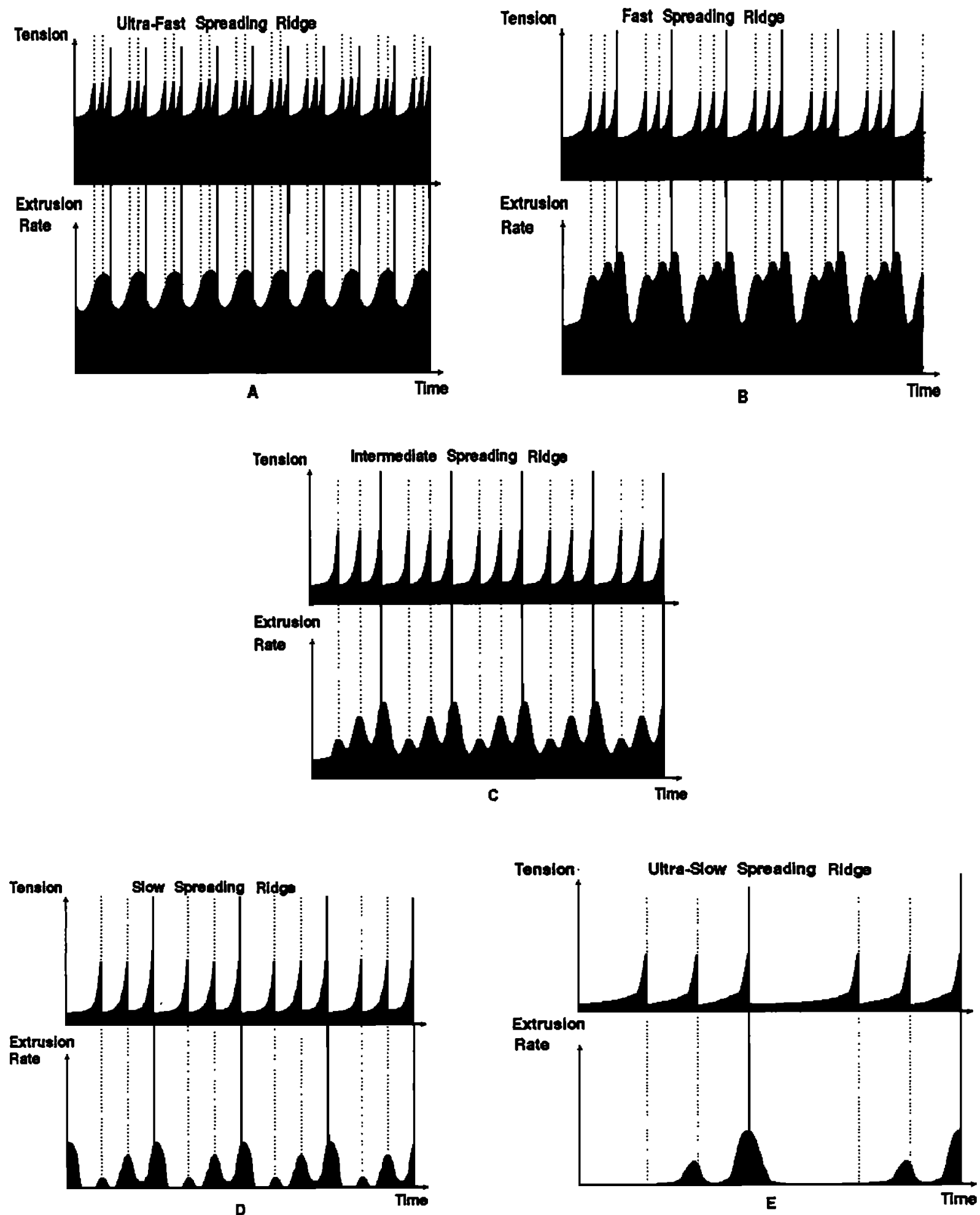

Figure 12. Idealized variation of the dynamics of the deep-seated and shallow level magmatic processes with spreading rate. The schemes are extrapolated from Figures 10 and 11 , assuming a three-step melting/accumulation/extraction model. (a) During magmatic periods, the high frequency of the magmatic events in the melting zone of ultrafast spreading ridges will smooth the volcanic events and the shortness of the amagmatic period will permit the formation of a near steady state magma reservoir. The variation in the constructional activity will be mainly regulated by the activity of the melting zone (recharge and discharge). (b-d) Decreasing frequency of the magmatic pulses and increasing duration of the amagmatic phase from fast to slow spreading ridges will progressively tend to increase the relative importance of volcanic events with respect to volcanic periods. (e) In the case of ultraslow spreading, part of the produced magma might never reach the surface because of high cooling rate during long-lasting amagmatic periods. 


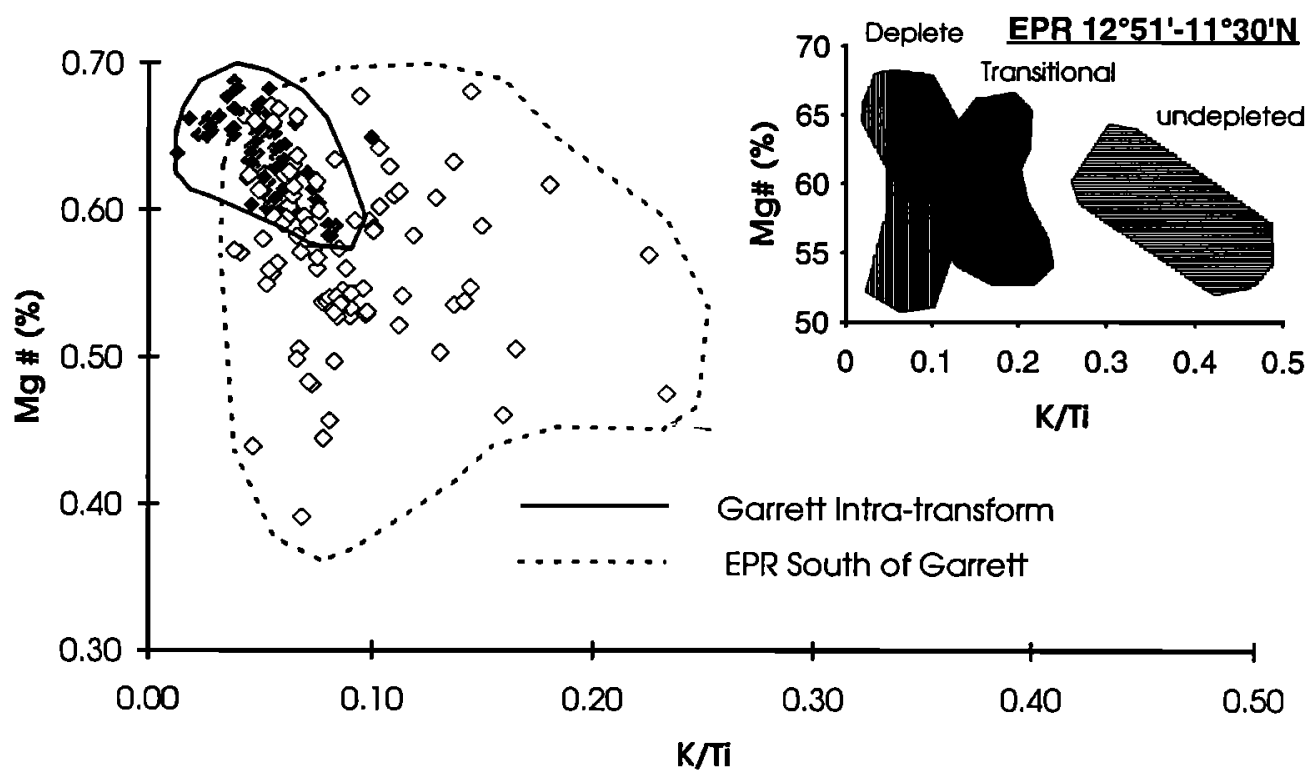

Figure 13. $\mathrm{Mg}$ number versus $\mathrm{K} / \mathrm{Ti}$ variation diagram of zero-age basaltic glasses from the ultrafast East Pacific Rise (EPR) axis south of $13^{\circ} \mathrm{S}$ and from the Garrett intratransform ridges. The distribution of EPR data [Sinton et al., 1991] probably integrates the effects of mixing and differentiation in a long-lived large-size magma chamber (see differences with EPR $13^{\circ} \mathrm{N}$ ). The distribution on the ultrafast EPR segment south of $13^{\circ} \mathrm{S}$ suggests that frequent replenishments of a long-lived near steady state magma chamber have buffered the compositions and that some mixing might occur between late depleted melts from a preceding magmatic cycle and early enriched melts from the next cycle. The intratransform volcanics [Hékinian et al., 1992] are depleted, primitive to moderately fractionated basalts which are often porphyritic.

melting cycle, increasing the duration of the amagmatic period at slow spreading ridges.

\section{Thermal Boundary Effects}

Transform fault offsets. Highly phyric basalts are curiously lacking on fast and ultrafast spreading ridges but are often sampled in fast and ultrafast strike-slip transform faults such as Garrett, Quebrada-Gofar and Siqueiros [Natland, 1980; Natland and Melson, 1980; Eissen et al., 1981; Natland, 1989]. These early observations were recently confirmed by systematic dredging on the EPR south of $13^{\circ} \mathrm{S}$ [Sinton et al., 1991], and by submersible studies of the Garrett [Hékinian et al., 1992] and Siqueiros [Ridley et al., 1991] intratransform volcanism. The basalts recently erupted on the inner floor of the Garrett transform are often porphyritic, depleted, and poorly differentiated when compared to the basalts produced at the EPR axis south of Garrett (Figures 4c and 13). The Garrett transform represents a cold barrier to the ascending mantle material, and the situation on the oblique inner ridges is comparable to that taking place at the extreme tip of a propagator or on ultraslow spreading ridges (Figures 11 and 12). The early produced melts are probably enriched magmas, but they generally freeze before reaching the transform floor [Hékinian et al., this issue]. This is corroborated by the presence of abundant gabbroic dikes and magmatic impregnation found in the serpentinized ultramafic outcrops on the northern wall of the E-W median ridge of the Garrett transform [Cannat et al., 1990; Hekinian et al., 1992]. However, high-pressure crystal fractionation in the mantle is also possible during freezing of small-size magma conduits between two magmatic periods or events, forming part of the observed gabbroic impregnations.
Overlapping spreading centers and minor offsets. As the correlations between the chemistry of MORBs and the physical characteristics of axial depth and crustal thickness probably reflect along strike variations in temperature of the underlying mantle [Klein and Langmuir, 1987, 1989; Niu and Batiza, 1993], this boundary effect should also occur in the vicinity of the overlapping spreading centers. However, it is probably complicated by the proximity of the ridge segments and should be more sensitive to variation in the thermal budget on both sides of the offsets than in the case of major transforms. This could explain the compositional variations recorded along the axis of the East Pacific Rise between $5^{\circ} 30^{\prime} \mathrm{N}$ and $14^{\circ} 30 \mathrm{~N}$, where the most contrasting compositions of basalt do not systematically correspond to the extremities of the ridge segments [Langmuir et al., 1986; Batiza, 1989] and where the complex distribution of E-MORBs should reflect both along strike and temporal variations at the axis of the ridge.

Off-axis volcanoes. The composition of the basalts extruded on off-axis seamounts $(<15 \mathrm{~km})$ near $13^{\circ} \mathrm{N}$ on the EPR show similar compositional variations to the lavas erupted on the nearby spreading center [Hekinian et al., 1989]. However, data collected from seamounts located on an older oceanic crust (> 2-3 Ma) sometimes show more enriched, or more depleted and more primitive compositions than the volcanics of the adjacent ridge axis [Batiza and Vanko, 1984; Davies and Karsten, 1986; Allan et al., 1989]. Also, the seamounts tend to show more isotopic diversity than the axis of the ridge [Batiza, 1989]. These variations with distance from the ridge axis could be explained in a similar way as for the tip of a propagator (Figures 11 and 12). For instance, seamounts erupted close to the axis are probably related to the main magmatic reservoir 
and have the same magmatic history as the spreading center. Instead, at some distance from the ridge axis, the cooling lithosphere containing small isolated pockets of melt will prevent any large extent of mixing and result in the extrusion of contrasted lava compositions. When the early enriched melts do not reach the surface as the result of high cooling rates, the next erupted lavas will tend to be primitive depleted melts (Figures 11 and 12). Enriched basalts could also be extruded by opening deep-seated pockets of enriched melts produced at the periphery of the melting zone away from the ridge axis (recall Figure 8).

\section{Influence of Mantle Heterogeneities}

Proximity of ridge hot spots and regional mantle heterogeneities. The proximity of a ridge hot spot (e.g., Azores plateau or Reykjanes Ridge) to an increased magma supply will modify this concept. The upper mantle and the crust are reheated, and the thermal conditions in the neighborhood of the hot spot should approach those encountered on intermediate to fast spreading ridges. In addition, the injection of fertile alkali components in the mantle plume will provide a considerable enrichment of the early produced melt increasing the contrast in composition of the lava erupted during a single magmatic/volcanic cycle. This is observed in the distibution of incompatible element and radiogenic isotope ratios in the vicinity of ridge hot spots of the MAR [White and Schilling, 1978; Hamelin et al., 1984; White et al., 1987; Dosso et al., 1993]. However, some rhythmicity in the petrological and geochemical zonations should persist if the small-scale distribution of the heterogeneities in the ascending mantle is regular for a long enough period of time (several cycles) and if significant fractionation occurs at the end of each cycle.

Chaotic distribution of small-scale mantle heterogeneities. The model proposed by Natland [1989] in order to explain the basalt compositional variations in the vicinity of Siqueiros transform fault assumes that various melts issued from chaotic mantle heterogeneities form isolated pockets which remain completely disconnected at the periphery of the melting zone. Assuming permeability zoning of the melting region (Figure 7), similar effects should originate by a model of multistage melt extraction with heterogeneities regularly distributed in the mantle. Sporadic injection of enriched blobs in the melting zone should only introduce scarce anomalies such as the occasional occurrence of alkali basalts among common depleted lavas (e.g., in the Siqueiros transform [Batiza et al., 1977]). However, increasing chaotic distribution should obliterate the expected rhythmicity of the basalt compositional zoning. If systematic sampling is carried out at a suitable statistical level, some rough rhythmicity might still appear. Indeed, cyclicity in the magmatic activity at depth should provide both contrasting basalt compositions before the formation of a sizable magma chamber and buffered compositions during high magma supply (mixing in a magma chamber). Finally, some extent of differentiation should affect the liquid in the magma chamber before complete freezing (crystallization) of the crystal-melt mush at the end of a magmatic cycle.

\section{Conclusions}

The distribution of the incompatible element and radiogenic isotope ratios of the basalt exposed at the axis of the EPR near $13^{\circ} \mathrm{N}$ and on off-axis seamounts less than $20 \mathrm{~km}$ apart is ex- plained by a model of multiphase melting of a composite mantle. This mantle is supposed to consist of a lherzolitic matrix including lenses of clinopyroxenite. However, the trace element ratios are satisfactorily explained by a multistage melt extraction model of nonmodal near-fractional melting ( $<1 \%$ melting increments) of a lherzolitic mantle source (olivine $49-55 \%$, opx 25-29\%, cpx 18-21\%, spinel 1-2\%). Application of a limited number (2-3) of accumulation/extraction steps gives sufficiently reliable results for less than 8-13\% total amount of melting (< 2.5-5\% melt aggregation in an accumulation zone located above the melting regime) and reasonable depletion of the final residue.

The final effects on surface lava composition are regulated by the contradictory effects of mixing and fractionation at shallow levels in the lithosphere. The results balance between the following two extreme conditions: (1) high magma supply with intense mixing in a near steady state magma chamber (ultrafast spreading ridges) which mainly results in homogeneization of the parental magmas and (2) low magma supply with disappearance of the magma chamber during long-lasting amagmatic periods (slow spreading ridges), resulting in production of contrasting lava compositions.

Scarce extrusions of high differentiates (i.e., ferro-basalts) might equally occur between the two extreme conditions, at the end of a magmatic cycle in absence of replenishment of the magma chamber, or as the result of in situ fractionation processes. In conditions of ultraslow spreading, or because of coldedge effects, rapid freezing of the ascending melts in the upper mantle or in the lower crust prevents extrusion of the early, enriched magmas and favors the extrusion of late, depleted melts (Garrett transform, MAR). Sporadic occurrence of very enriched composition (i.e., alkali basalts) might occur in such a cold environment when occasional injection of a larger amount of fertile component in the mantle increases locally and temporarily the amount of melt supply.

Comparing different regions of the world's mid-ocean ridges is a difficult task because regional and local chemical anomalies in the mantle affect the distribution of the small-scale heterogeneities. When this distribution is regular, detailed on- and off-axis studies of a propagating ridge or a single ridge segment should reveal some recurrences of basalt compositional zoning. However, sporadic concentrations of enriched component in the mantle should introduce anomalies, and chaotic distribution of the mantle heterogeneity at every scale should completely obliterate this zoning.

The current physical models of partial melting in the mantle are steady state and do not take into account fluctuations in the magmatic activity through time. The present study suggests that the dynamics of the melting zone and the rate of magma supply at shallow levels are controlled by the thermal and tensional regime both in the deep-seated mantle and in the ascending mantle column as the result of discontinuous extraction of magma. The rapid migration of the melt toward shallow levels should induce relaxation in the tension field and contraction of the melting zone. When repeated several times during a magmatic cycle, this process will result in successive pulses, acting as a pump. However, some aspects of the problem explored in the present paper remain, highly speculative because of the multiplicity of interacting parameters which are currently not very well constrained.

The existence of magmatic cycles including multiphase melting and discontinuous extraction imply numerous constraints on the physics of the upper mantle and crust and on the 
dynamics of the magmatic processes. Further works on this topic have to consider the variations in morphology and tensional regime of the melting zone as the result of discontinuous extraction, and the consequences on the thermal budget of the upper mantle and lower crust. This will provide new insights on mid-ocean ridge magmatism and the interactions of basaltic melts with the residual mantle (gabbroic impregnations) and on related processes such as hydrothermal convection and the alteration of the ocean crust.

\section{Appendix}

\section{Multistage Melting Extraction Model}

Assumptions. Mantle melting is assumed to be incremental and near-fractional. The size of the increments (or "batches") is small ( $<1 \%)$ and controlled by the permeability threshold of the mantle source (here taken as $1 \%$ of the melting solid). Incomplete melt withdrawal during segregation is also assumed ( $10 \%$ of the melt produced at each stage). These conditions are kept constant over the entire range of melting.

$F \quad$ proportion of melt $(F=0.01)$ before each extraction (permeability threshold);

$t$ proportion of trapped liquid in the melting solid ( $t=$ $0.001 ; 0.1 \%$ of the initial solid $S_{0}$ );

$n$ number of extractions or melting increments;

$X_{n} \quad$ proportion of the residual solid $\left(X_{0}=1\right)$;

$X_{i, n} \quad$ proportion of mineral phase $i$ in the solid $\left(X_{i, 0}\right.$ is the modal proportion in $S_{0}$ );

$K_{i} \quad$ stoichiometric coefficient of melting phase $i$;

$d_{i} \quad$ partition coefficient of a given element in mineral phase $i$;

$D_{n} \quad$ bulk partition coefficient of the solids at each stage;

$P_{n} \quad$ bulk partition coefficients of the melting phases at each stage;

$\mathrm{Cl}_{n}$ concentration of a given element in the liquid fraction;

$C L_{n}$ concentration of a given element in the aggregated liquid;

$C S_{n}$ concentration of a given element in the residual solid.

The following mass fractions refer to the initial solid $S_{0}$.

$f_{n} \quad$ mass fraction of melt $\left(f_{0}=F\right)$ produced before each extraction (melting increment);

$x_{n} \quad$ mass fraction of the solid before each extraction $\left(x_{0}=\right.$ $X_{0}=1$ );

$x_{i, n} \quad$ mass fraction of phase $i$ in the solid before each extraction $\left(x_{i, 0}=X_{i, 0}\right)$;

$t_{n} \quad$ mass fraction of liquid trapped in the solid after each extraction $\left(t_{0}=0\right)$;

$e_{n} \quad$ mass fraction of extracted melt at each stage $\left(e_{0}=0\right)$;

$f_{n}=\left[F^{*}\left(x_{n-1}+t_{n-1}\right)\right]-t_{n-1}$;

$x_{n}=x_{n-1}-f_{n}+t_{n-1}$

$t_{n}=t^{*}\left(x_{n-1}+t_{n-1}\right)$

$e_{n}=f_{n}+t_{n-1}-t_{n}$

$F_{n}=f_{n} / x_{n-1}$

$X_{n}=1-F_{n}$

$T_{n}=t_{n} / x_{n-1}$

$E_{n}=E_{n-1}+e_{n}$ with $E_{0}=0$ and $E_{1}=e_{1}=F-t$,

$A$ maximum proportion of melt in the accumulation zone (permeability threshold); $m$ number of extractions from the accumulation zone;

$C a_{n}$ concentration of a given element in the accumulated melt $(\mathrm{Ca}=0)$;

$C e_{m}$ concentration of a given element in the melt extracted from the accumulation zone $\left(\mathrm{Ce}_{0}=0\right)$;

$A_{n} \quad$ mass fraction of accumulated melt at each step of melting $\left(A_{0}=0\right)$;

$T_{m} \quad$ proportion of liquid trapped after extraction from the accumulation zone $\left(T_{0}=0 ; T_{m}=T\right)$;

$T$ arbitrarily considered as $10 \%$ of the liquid accumulated at each step.

Equations for the melting zone.

$X_{i, n}=\left[\left(x_{i, n-1} / x_{n-1}\right)-\left(K_{i} * F_{n-1}\right)\right]$

$D_{n}=\Sigma\left(X_{i, n}^{*} d_{i}\right)$

$P_{n}=\Sigma\left(K_{i}^{*} d_{i}\right)$

with $P_{n}=P$

$K_{i}$ is the average coefficient of phase $i$ estimated by Kinzler and Grove [1992a] for spinel-lherzolites. $K_{i}$ is kept constant over entire melting range. Thus $P_{n}$ is constant. The following calculations concern a near-fractional melting model (nonmodal incremental batch melting) of a lherzolitic mantle source. The equations are derived from Shaw [1970]:

$C l_{n}=\left[\left(\left(X_{n} * C S_{n-1}\right)+\left(T_{n} * C l_{n-1}\right)\right) /\left(X_{n}+T_{n}\right)\right]$

$/\left[D_{n-1}+\left(F_{n} *(1-P)\right)\right]$

$C S_{n}=\left[\left(\left(X_{n} * C S_{n-1}\right)+\left(T_{n} * C l_{n-1}\right)\right) /\right.$

$\left.\left.\left(X_{n}+T_{n}\right)\right]-\left[F_{n} * C l_{n}\right]\right] / X_{n}$

Starting conditions. The concentration of a given trace element in the first enriched melt is $\mathrm{Cl}_{1}$ :

$C l_{1}=C S_{0} /\left[D_{0}+F(1-P)\right]$

$D_{0}$ is the bulk partition coefficient during the first step. The concentration of the element in the residual solid after the first stage of extraction is as follows:

$C S_{1}=\left[C S_{0}-\left(F^{*} C l_{1}\right)\right] /(1-F)$.

Equations (A6) and (A7) are the equations for nonmodal batch melting after Shaw [1970].

Equations for the accumulation zone. The melts produced are supposed to aggregate without reequilibration in a refractory mantle located somewhere above the melting zone. The composition of the aggregated melt at each step of melting (melting curves for melt composition) is simply the sum of the incremental melt portions:

$C L_{n}=\left[\left(E_{n-1} * C L_{n-1}\right)+\left(e_{n} * c l_{n}\right)\right] / E_{n}$.

In the case of the multistage melt extraction process, the conditions in the melting zone are the same as defined above, but accumulation is discontinuous:

$\begin{array}{ll}A_{n}=A_{n-1}+e_{n} & \text { if } A_{n}<A \\ A_{n}=\left(A_{n-1} * T\right)+e_{n} & \text { if } A_{n}=A\end{array}$

The concentration of a given element in the accumulation zone at each step is obtained by the following equations: 
$C a_{n}=\left[\left(A_{n-1} * C a_{n-1}\right)+\left(e_{n} * C l_{n}\right)\right] / A_{n}$ If $A_{n}<A$

$C e_{m}=C a_{n} \quad A_{n}=A$

If $C e_{m}=C a_{n}$ then $C a_{n}=\left[\left(A_{n-1} * T * C a_{n-1}\right)+\left(e_{n} * C l_{n}\right)\right] /$ $A_{n}$

In the case of the mantle source $\mathrm{Ib} / 8$ (see text for explanations) and two-steps of extraction ( $m=0$ to 2 ), the permeability threshold in the accumulation zone $(A)$ needs to reach $10 \%$ of solid in order to fit the data of the EPR near $13^{\circ} \mathrm{N}$ and the Garrett fracture zone. For three steps of extraction ( $m=$ 0 to 3 ), the best fit is obtained for $A<5 \%$. In each case the total amount of melting is less than $15 \%$. The mantle source used by Johnson et al. [1990], and referred here as Lb75, gives similar results for three steps of extraction with $A<2.5 \%$ and a total amount of melting of $8 \%$.

Acknowledgments. This work was supported by the Department of Marine Geosciences (IFREMER). We are grateful to James Natland for his useful critical comments of a previous version of the manuscript. We also geatly appreciated the comments by Gregg Bluth (Associate Editor) and two anonymous reviewers in order to improve the manuscript. Rodey Batiza is particularly thanked for helpful discussions.

\section{References}

Allan, J.F., R. Batiza, M.R. Perfit, D.J. Fornari, and R.O. Sack, Potrology of lavas from the Lamont seamount chain and adjacent East Pacific Rise, 10N, J. Petrol., 30, 1245-1298, 1989.

Arcyana, Rocks collected by bathyscaph and diving saucer in the FAMOUS area of the Mid-Atlantic Rift Valley: Petrological diversity and structural setting, Deep Sea Res., 24, 565-589, 1976.

Bass, M., Variable abyssal basalt populations and their relation to sea-floor spreading rates, Earth Planet. Sci. Lett., 11, 18-22, 1971.

Batiza, R., Petrology and geochemistry of eastern Pacific spreading centers, in The Geology of North America, vol. N, The Eastern Pacific Ocean and Hawaii, edited by E.L. Winterer, D.M. Hussong, and R.W. Decker, pp. 145-159, American Geological Society, Boulder, Colo., 1989.

Batiza, R., and D.A. Vanko, Petrology of young Pacific seamounts, J. Geophys. Res., 89, 11235-11260, 1984.

Batiza, R., B.R. Rosendahl, and RL. Fisher, Evolution of oceanic crust, 3, Petrology and chemistry of basalts from the East Pacific Rise and Siqueiros transform fault, $J$. Geophys. Res., 82, 265276, 1977.

Bideau, D., R. Hébert, R. Hekinian, and M. Cannat, Metamorphism of deep-seated rocks from the Garrett ultrafast transform (East Pacific Rise near 1325'S), J. Geophys. Res., 96, 10,079-10,099, 1991.

Bougault, H., P. Cambon, O. Corre, J.L. Joron, and M. Treuil, Evidence for variability of magmatic processes and upper mantle heterogeneity in the axial region of the Mid-Atlantic Ridge near $22^{\circ}$ and 36 N, Tectonophysics, 55, 11-34, 1979.

Bryan, W.B., and J.G. Moore, Compositional variations of young besalts in the Mid-Atlantic Ridge rift valley near lat $36^{\circ} 49 \mathrm{~N}$, Geol. Soc. Am Bull., 88, 556-570, 1977.

Bryan, W. B., G. Thompson, and P.J. Michael, Compositional variation in steady-state magma chamber. Mid-Atlantic Ridge at 3650'N, Tectonophysics, 55, 63-85, 1979.

Bulau, J.R, H.S. Waff, and J.A Tyburczy, Mechanical and thermodynamic constraints on the fluid distribution in partial melts, $J$. Geophys. Res., 84, 6102-6108, 1979.

Burnett, M.S., D.W. Caress, and J.A. Orcutt, Tomographic image of the magma chamber at $12^{\circ} 50 \mathrm{~N}$ on the East Pacific Rise, Nature, 339, 206-208, 1989.
Bussod, G.Y., and J.M. Christie, Textural development and melt topology in spinel therzolite experimentally deformed at hypersolidus conditions, in Orogenic Lherzolites and Mantle Processes, $J$. Petrol., Spec. Vol., 17-39, 1991.

Cannat, M., Emplacement of mantle rocks in the seafloor of midocean ridges, J. Geophys. Res., 98, 4163-4172, 1993.

Cannat, M., D. Bideau, and R. Hebert, Plastic deformation and melt impregnation in serpentinized ultramafic rocks from the Garrett transform fault (East Pacific Rise), Earth Planet. Sci. Lett., 101, 216-232, 1990.

Cannat, M., D. Bideau, and H. Bougault, Serpentinized peridotites and gabbros in the Mid Atlantic Ridge axial valley at $15^{\circ} 37 \mathrm{~N}$ and 1652'N, Earth Plonet. Sci. Lett., 109, 87-106, 1992.

Caress, D.W, M.S. Burnett, and J.A. Orcutt, Tomographic image of the axial low-velocity zone at $12^{\circ} 50 \mathrm{~N}$ on the East Pacific Rise, $J$. Geophys. Res., 97, 9243-9263, 1992.

Choukroune, P., J. Francheteau, and R. Hekinian, Tectonics of the East Pacific Rise near $12^{\circ} 50$ N: A submersible study, Earth Planet. Sci. Lett., 68, 115-127, 1984.

Christie, D.M., and J.M. Sinton, Evolution of abyssal lavas along propagating segments of the Galapagos Spreading Center, Earth Planet. Sci. Lett., 56, 321-335, 1981.

Clague, D.A. F.A. Frey, G. Thompson, and S.J. Rindge, Minor and trace element geochemistry of volcanic rocks dredged from the Galapagos Spreading Center. Role of crystal fractionation and mantle inhomogeneity, J. Geophys. Res., 86, 9469-9482, 1981.

Cooper, RF., and D.L. Kohlsted, Solution-precipitation enhanced diffusional creep of partially molten olivine-basalt aggregates during hot-pressing. Tectonophys. 107, 9315-9323, 1984.

Cordery, M.J., and J. Phipps Morgan, Melting and mantle flow boneath a mid-ocean spreading center, Earth Planet. Sci. Lett., 111 , 493-516, 1992

Cordery, M.J., and J. Phipps Morgan, Convection and melting at mid-ocean ridges, J. Geophys. Res., 98, 19,477-19,503, 1993.

Daines, M.J., and F.M. Richter, An experimental method for directly determining the interconnectivity of melt in a partially molten system, Geophys. Res. Lett., 15, 1459-1462, 1988.

Davies, E.E., and J.L. Karsten, On the cause of asymmetric distribution of seamounts about the Juan de Fuca Ridge: Ridge crest migration over a heterogeneous asthenosphere, Earth Planet. Sci. Lett., 79, 385-396, 1986.

Devey, C.W., C.-D. Garbe-Schönberg, P. Stoffers, C. Chauvel, and D.F. Mertz, Geochemical effects of dynamic melting beneath ridges: Reconciling major and trace element variations in Kolbeinsey (and global) mid-ocean ridge basalts, J. Geophys. Res., 99, 9077-9095, 1994.

Detrick, R.S., P. Buhl, E. Vera, J. Mutter, J. Orcutt, J. Madsen, and T. Brocher, Multi-channel seismic imaging of a crustal magma chamber along the East Pacific Rise, Nature, 326, 35-41, 1987.

Dick, H.J.B., Abyssal peridotites, very slow spreading ridges and ocean ridge magmatism, in Magmatism in the Ocean Basins, edited by A.D. Saunders and M.J. Norry, Geol. Soc. Spec. Publ. London, 42, 71-105, 1989.

Dick, HJ.B., R.L. Fisher, and W.B. Bryan, Mineralogic variability of the uppermost mantle along mid-ocean ridges, Earth Planet. Sci. Lett., 69, 88-106, 1984.

Dosso, L., H. Bougault and J.-L. Joron, Geochemical morphology of the north Mid-Atlantic Ridge, $10^{\circ}-24^{\circ} \mathrm{N}$ : Trace element-isotope complementarity, Earth Plonet. Sci. Lett., 120, 443-462, 1993.

Duncan, R.A, and D.H. Green, Role of multistage melting in the formation of occanic crust, Geology, 8, 22-26, 1980.

Dupré, $\mathrm{B}$., and C.J. Allègre, $\mathrm{Pb}-\mathrm{Sr}$-Nd isotopic correlation and the chemistry of the North Atlantic mantle, Nature, 286, 17-22, 1980.

Edwards, M.H., D.J. Fomary, A. Malinvemo, and W.B.F. Ryan, The regional tectonic fabric of the East Pacific Rise from $12^{\circ} 50 \mathrm{~N}$ to 15'10N, J. Geophys. Res., 96, 7995-8017, 1991.

Eissen, J.-P., D. Bideau, and T. Juteau, Présence de basaltes porphyriques dans les zones de fractures de la dorsale Est-Pacifique, C. R Acad. Sci. Ser.2, 293, 61-65, 1981. 
Elthon, D., Pressure of origin of primary mid-ocean ridge basalts, in Magmatism in the Ocean Basins, edited by A.D. Saunders and M.J. Norry, Geol. Soc. Spec. Publ. London, 42, 125-136, 1989.

Forsyth, D.W., Crustal thickness and the average depth and degree of melting in fractional melting models of passive flow beneath mid-ocean ridges, J. Geophys. Res., 98, 16,073-16,079, 1993.

Frey, F.A., C.J. Suen, and H.W. Stockman, The Ronda high temperature peridotite: Geochemistry and petrogenesis, Geochim Cosmochim Acta, 49, 2469-2491, 1985.

Gente, P., J.M. Auzende, V. Renard, Y. Fouquet, and D. Bideau, Detailed geological mapping by submersible of the East Pacific Rise axial graben near 13\%, Earth Planet. Sci. Lett., 78, 224-236, 1984.

Gilluly, J., Plate tectonics and magmatic evolution, Bull. Geol. Soc. $A m, 82,2383-2396,1971$.

Green, D.H., Composition of basaltic magmas as indicators of conditions of origin: Application to oceanic volcanism, Philos. Trans. R. Soc. London A, 268, 707-725, 1971.

Hamelin, B., B. Dupre, and C.J. Allegre, Lead-strontium isotopic variations along the East Pacific Rise and Mid-Atlantic Ridge; A comparative study, Earth Planet. Sci. Lett., 67, 340-350, 1984.

Haymon, R.M., D.J. Fornari, M.H. Edwards, S. Carbotte, D. Wright, and K. Macdonald, Hydrothermal vent distribution along the East Pacific Rise crest $\left(9^{\circ} 09^{\prime}-54 \mathrm{~N}\right)$ and its relationship to magmatic and tectonic processes on fast-spreading mid-ocean ridges, Earth Planet. Sci. Lett., 104, 513-534, 1991.

Hékinian, R., and D. Walker, Diversity and spatial zonation of volcanic rocks from the East Pacific Rise near $21^{\circ} \mathrm{N}$, Contrib. Mineral. Petrol., 96, 265-280, 1987.

Hékinian, R., J. Francheteau, and R.D. Ballard, Morphology and evolution of hydrothermal deposits at the axis of the East Pacific Rise, Oceanol. Acta, 8, 147-155, 1985.

Hékinian, R., G. Thompson, and D. Bideau, Axial and off-axial heterogeneity of basaltic rocks from the East Pacific Rise at $12^{\circ} 35 \mathrm{~N}-$ $12^{\circ} 51 \mathrm{~N}$ and $11^{\circ} 26^{\mathrm{N}}-11^{\circ} 30 \mathrm{~N}, J$. Geophys. Res., 94, 17,437$17,463,1989$.

Hékinian, R., D. Bideau, P. Stoffers, J.L. Cheminée, R. Mühe, D. Puteanus, and N. Binard, Submarine intraplate volcanism in the south Pacific: Geological settings and petrology of the Society and the Austral regions, J. Geophys. Res., 96, 2109-2138, 1991.

Hékinian, R., D. Bideau, M. Cannat, J. Francheteau, and R. Hebert, Volcanic activity and crust-mantle exposure in the ultrafast Garrett transform fault near $13^{\circ} 28$ 'S in the Pacific, Earth Planet. Sci. Lett., 108, 259-275, 1992.

Hékinian, R., D. Bideau, J. Francheteau, J.L. Cheminée, R. Armijo, P. Lonsdale, and N. Blum, Petrology of the East Pacific Rise crust and upper mantle exposed in the Hess Deep (Eastern Equatorial Pacific), J. Geophys. Res., 98, 8069-8094, 1993.

Hékinian R., D. Bideau, R. Hébert, and Y. Niu, Magmatism in the Garrett transform fault (East Pacific Rise near 13\%27N), J. Geophys. Res., this issue.

Hey, R.N., J.M. Sinton, and F.K. Duennebier, Propagating rift and spreading centers, in The Geology of North America, vol. N, The Eastern Pacific Ocean and Hawaii, edited by E.L. Winterer, D.M. Hussong, and RW. Decker, p.p. 161-175, Geological Society of America, Boulder, Colo., 1989.

Holness, M.B., and F.M. Richter, Possible effects of spreading rate on MORB isotopic and rare earth composition arising from melting of a heterogeneous source, J. Geol., 97, 247-260, 1989.

Irving, A.J., Petrology and geochemistry of composite ultramafic xenoliths in alkalic basalts and implications for magmatic processes within the mantle, Am. J. Sci., 280-A, 389-426, 1980.

Johnson, K.T.M., H.J.B. Dick, and N. Shimiza, Melting in oceanic upper mantle: An ion microprobe study of diopsides in abyssal peridotites, J. Geophys. Res., 95, 2661-2678, 1990.

Kappel, E.S., and W.B.F. Ryan, Volcanic episodicity and non-steady state rift valley along northeast pacific spreading centers: Evidence from Sea Marc I, J. Geophys. Res., 91, 13,925-13,940, 1986.
Karson, J.A., et al., Along axis variations in seafloor spreading in the MARK area, Nature, 328, 681-685, 1987.

Kent, G.M., A.J. Harding, and J.A. Orcutt, Evidence for a smaller magma chamber beneath the East Pacific Rise at $9^{\circ} 30 \mathrm{~N}$, Nature, $344,650-653,1990$.

Kinzler, R.J., and T.L. Grove, Primary magmas of mid-ocean oidge basalts, 1, Experiments and methods, J. Geophys. Res., 97, 68856906, 1992a.

Kinzler, R.J., and T.L. Grove, Primary magmas of mid-ocean ridge basalts, 2, Applications, J. Geophys. Res., 97, 6907-6926, 1992b.

Klein, E.M., and C.H. Langmuir, Global correlations of ocean ridge basalt chemistry with axial depth and crustal thickness, $J$. Geophys. Res., 92, 8089-8115, 1987.

Klein, E.M., and C.H. Langmuir, Local versus global variations in ocean ridge basalt composition: A reply, J. Geophys. Res., 94, 4241-4252, 1989.

Kuo, B.-Y., and D.W. Forsyth, Gravity anomalies of the ridge transform system in the south Atlantic between $31^{\circ}$ and $34.5^{\circ} \mathrm{S}$ : Upwelling centers and variations in crustal thickness, Mar. Geophys. Res., 10, 205-232, 1988.

Langmuir, C.H., Geochemical consequence of "in situ" crystallization, Nature, 340, 199-205, 1989.

Langmuir, C.H., J.F. Bender, AE. Bence, and G.N. Hanson, Petrogenesis of basalts from the FAMOUS area: Mid-Atlantic Ridge, Earth Planet. Sci. Lett., 36, 133-156, 1977.

Langmuir, C.H., J.F. Bender, and R. Batiza, Petrological and tectonic segmentation of the East Pacific Rise, $5^{\circ} 30^{\prime}$ to $14^{\circ} 30 \mathrm{~N}$, Nature, $322,422-429,1986$

Langmuir, C.H., E.M. Klein, and T. Plank, Petrological systematics of mid-ocean ridge basalts: Constraints on melt generation beneath ocean ridges, in Mantle Flow and Melt Generation at MidOcean Ridges, edited by D.K. Blackman and J.M. Sinton, pp. 155-183, Geophys. Monogr. S'er., vol. 71,, AGU, Washington, D.C., 1992.

Lewis, B.T.R., Periodicities in volcanism and longitudinal magma flow on the East Pacific Rise at $23^{\circ} \mathrm{N}$, Geophys. Res. Lett., 6, 10, 753-756, 1979.

Lin, J., and J. Phipps Morgan, The spreading rate dependence of 3-D mid-ocean ridge structure, Geophys. Res. Lett., 19, 13-16, 1992.

Lin, J., G.M. Purdy, H. Schouten, J.-C. Sempere, and C. Zervas, Evidence from gravity data for focussed magmatic accretion along the Mid-Atlantic Ridge, Nature, 344, 627-632, 1990.

Lister, C.R.B., Qualitative models of spreading center processes, including hydrothermal penetration, Tectonophysics, 37, 203-218, 1977.

Loubet, M., N. Shimizu, and C.J. Allègre, Rare earth elements in alpine peridotites, Contrib. Mineral. Petrol., 53, 1-12, 1975.

Maaloe, S., Geochemical aspects of permeability controlled partial melting and fractional crystallization, Geochim. Cosmochim Acta, 46, 43-57, 1981.

Maaloe, S., and S.P. Jakobsson, The PT phase relations of primary oceanite from the Reykjanes peninsula, Iceland, Lithos, 13, 237$246,1980$.

Maaloe, S., and I. Printzlau, Natural partial melting of spinel therzolite, J. Petrol., 20, 727-741, 1979.

Malinverno, A, and P.A. Cowie, Normal faulting and the topographic roughness of mid-ocean ridge flanks, $J$. Geophys. Res., 98, 17,921-17,939, 1993.

MoClain, K.J., and B.T.R. Lewis, Geophysical evidence for the absence of a crustal magma chamber under the northern Juan de Fuca Ridge: A contrast with ROSE results, J. Geophys. Res., 87, 8477-8489, 1982.

McDonough, W.F., H.-G. Stosch, and N.G. Ware, Distribution of titanium and rare earth elements between peridotic minerals, Contrib. Mineral Petrol., 110, 321-328, 1992.

McKenzie, D., The generation and compaction of partially molten rock, J. Petrol. 25, 713-765, 1984.

McKenzie, $D_{\text {., }}{ }^{230}{ }^{T h}-{ }^{238} \mathrm{U}$ disequilibrium and the melting processes beneath ridge axes, Earth Planet. Sci. Lett., 72, 149-157, 1985. 
McKenzie, D. and M.J. Bickle, The volume and composition of melt generated by extension of the lithosphere, J. Petrol., 29, 625-679, 1988.

Melson, W.G., T.L. Vallier, T.L. Wright, G. Byerly, and J. Nelen, Chemical diversity of abyssal volcanic glass erupted along Pacific, Atlantic, and Indian sea-floor spreading centers, in The Geophysics of the Pacific Ocean Basin and Its Margin, Geophys. Monogr. Ser., 19, edited by G.H. Sutton, M.H. Manghani, R. Moberly, pp. 351-367, AGU, Washington, D.C., 1976.

Morel, J.M., and R. Hekinian, Compositional variations of volcanics along segments of recent spreading ridges, Contrib. Mineral. Petrol., 72, 425-436, 1980.

Natland, J.H., Crystal morphologies in basalts dredged and drilled from the East Pacific Rise near 9\% $\mathrm{N}$ and the Siqueiros fracture zone, Init. Rep. DSDP, 54, 605-633, 1980.

Natland, J.H., Partial melting of a lithologically heterogeneous mantle: Inferences from crystallization histories of magnesian abyssal tholeites from the Siqueiros fracture zone, in Magmatism in the Ocean Basins, edited by Saunders AD. and M.J. Norry, Geol. Soc. Spec. Publ. London, 42, 41-70, 1989.

Natland, J.H., and W.G. Melson, Composition of basaltic glasses from the East Pacific Rise and Siqueiros fracture zone, near $9 \%$, in Initial Rep. Deep Sea Drill. Proj., 54, 705-723, 1980.

Nicolas, A, A melt extraction model based on structural studies in mantle peridotites, J. Petrol., 27, 4, 999-1022, 1986.

Nicolas, A, and M. Jackson, High temperature dikes in peridotites: Origin of hydraulic fracturing, J. Petrol., 23, 568-582, 1982.

Nisbet, E.G., and C.M.R. Fowler, The Mid-Atlantic Ridge at 37 and $45^{\circ} \mathrm{N}$ : Some geophysical and petrological constraints, Geophys. J. $R$ astron. Soc., 54, 631-660, 1978.

Niu Y. and RD. Batiza, An empirical method for calculating melt compositions produced beneath Mid-Ocean Ridges: Application for axis and off-axis (seamounts) melting. J. Geophys. Res., 96, 21,753-21,777, 1991.

Niu Y. and R.D. Batiza, Chemical variation trends at fast and slow spreading mid-ocean ridges, J. Geophys. Res., 98, 7887-7902, 1993.

Oxburgh E.R., Heat flow and magma genesis, in Physics of Magmatic Processes, edited by R.B. Hargraves, pp. 161-199, Princeton University Press, Princeton, N.J., 1980.

Pallister, J.S, and C.A Hopson, Samail ophiolite plutonic suite: Fields relations, phase variation, cryptic variation and layering, and a model of a spreading ridge magma chamber, $J$. Geophys. Res., 86, 2593-2644, 1981.

Pearce, J.A., and J.R. Cann, Ophiolite origin investigated by discriminant analyses using $\mathrm{Ti}, \mathrm{Zr}$, and $\mathrm{Y}$, Earth Planet. Sci. Lett., 12, 339-349, 1971.

Pearce, J.A., and J.R. Cann, Tectonic setting of basic volcanic rocks determined using trace element analyses, Earth Planet. Sci. Lett., 19, 290-300, 1973.

Phipps Morgan, J., Melt migration bebeath mid-ocean spreading centers, Geophys. Res. Lett., 14, 1238-1241, 1987.

Plank, T.P., and C.H. Langmuir, Effects of the melting regime on the composition of the ocean crust, $J$. Geophys. Res., 97, 19,74919,770, 1992.

Pockalny, R.A., R.S. Detrick and P.J. Fox, Morphology and tectonics of the Kane transform from Sea Beam bethymetry data, J. Geophys. Res., 93, 3179-3193, 1988.

Prinzhofer, A, and C.J. Allègre, Residual peridotites and the mechanisms of partial melting, Earth Planet. Sci. Lett., 74 251$265,1985$.

Prinzhofer, A, E. Lewin, E., and C.J. Allègre, Stochastic melting of the marble cake mantle: Evidence from local study of the East Pacific Rise at $12^{\circ} 50$ N, Earth Planet. Sci. Lett., 92, 189-206, 1989.

Purdy, G.M., and R.S. Detrick, Crustal structure of the Mid-Atlantic Ridge at $23 \% \mathrm{~N}$ from seismic refraction studies, $J$. Geophys. Res., 91, 3739-3762, 1986.

Rabinowicz, M., G. Ceuleneer, and A. Nicolas, Melt segregation and flow in mantle diapirs below spreading centers: Evidence from the Oman ophiolite, J. Geophys. Res., 92, 3475-3486, 1987.

Reid, I., and H.R. Jackson, Oceanic spreading rate and crustal thickness, Mar. Geophys. Res., 5, 165-172, 1981.

Reynolds R.J., C.H. Langmuir, J.F. Bender, K.A. Kastens and W.B.F. Ryan, Spartial and temporal variability in the geochemistry of basalt from the East Pacific Rise, Nature, 359, 493-499, 1992.

Ribe, N.M., The deformation and compaction of partial molten zones, Geophys. J.R. Astron. Soc., 83, 487-501, 1985.

Richter, F.M., and D. McKenzie, Dynamical models for melt segregation from a deformable matrix, J. Geol. 92, 729-740, 1984.

Ridley, W.I., M.R. Perfit, P. Kirk, J. Casey and D. Fornari, Picritic basalts and magnesian glasses from Sequeiros transform fault, Eos Trans AGU, 72 (44), Fall Meeting Suppl., 526, 1991.

Riley, G.N., D.L. Kohlstedt, and F.M Richter, Melt migration in a liquid-olivine system: An experimental test of compaction theory, Geophys. Res. lett., 17, 2101-2104, 1990.

Rubin, K.H., and J.D. MacDougall, $226 \mathrm{Ra}$ excesses in mid-ocean ridge basalts and mantle melting, Nature, 335, 158-161, 1988.

Scheidegger, K.F., Temperature and compositions of magmas ascending along mid-ocean ridges, $J$. Geophys. Res., 78, 33403355, 1973.

Schilling J.-G., Iceland mantle plumes: Geochemical evidence along Reykjanes Ridge, Nature, 242, 565-571, 1973.

Scott, D.R., and D.J. Stevenson, Magma ascent by porous flow, $J$. Geophys. Res., 91, 9283-9296, 1986.

Scott, D.R., and D.J. Stevenson, A self-consistent model of melting magma migration and buoyancy-driven circulation beneath midocean ridges, J. Geophys. Res., 94, 2973-2988, 1989.

Shaw, D.M., Trace element fractionation during anatexis, Geochim Cosmochim. Acta, 34, 237-243, 1970.

Shervais, J.W., Ti-V plots and the genesis of modern and ophiolitic lavas, Earth Plonet. Sci. Lett., 59, 101-118, 1982.

Sinton, J.M., and R.S. Detrick, Mid-ocean ridge magma chambers, $J$. Geophys. Res., 97, 197-216, 1992.

Sinton, J.M., S.M. Smalik, J.J. Mahoney, and K.C. Macdonald, Magmatic processes at superfast spreading ridges: Glass compositional variations along the East Pacific Rise $13^{\circ}-23^{\circ} \mathrm{S}, J$. Geophys. Res., 96, 6133-6155, 1991.

Sleep, N.H., Segregation of magma from a mostly crystalline mush, Geol. Soc. Amer. Bull., 85, 1225-1232, 1974.

Sleep, N.H., Formation of oceanic crust: Some thermal constraints, $J$. Geophys. Res., 80, 4037-4042, 1975.

Sleep, N.H., Tapping of magmas from ubiquitous mantle heterogeneities, an alternative model to mantle plumes?, J. Geophys. Res. 89, 10029-10041, 1984.

Sotin, C., and E.M Parmentier, Dynamical consequences of compositional and thermal density stratification beneath spreading centers, Geophys. Res. Lett., 16, 835-838, 1989.

Sparks, D.W., and E.M. Parmentier, Melt extraction from the mantle beneath spreading centers, Earth Planet. Sci. Lett., 105, 368-377, 1991.

Spiegelman, M., Physics of melt extraction: Theory, implication and applications, Philos. Trans. $R$. Soc. London, A, 342, 23-41, 1993.

Stosch,H.-G., and H.A. Seck, Geochemistry and mineralogy of two spinel peridotites suites from Dreiser Weiher, West Germany, Geochim Cosmochim. Acta, 44, 457-470, 1980.

Sun, S.S., and W.F. McDonough, Chemical and isotopic systematics of oceanic basalts: implications for mantle composition and processes, in Magmatism in the Ocean Basins, edited by AD. Saunders and M.J. Norry, Geol. Soc. Spec. Publ. London, 42, 313345, 1989.

Turcotte, D.L., and J.L. Ahren, A porous flow model for magma migration in the asthenosphere, $J$. Geophys. Res., 83, 767-772, 1978.

Von Bargen, N., and H.S. Waff, Permeabilities, interfacial areas, and curvatures of partially molten systems: Results of numerical computations of equilibrium microstructures, $J$. Geophys. Res., 91, 9261-9276, 1986. 
Waff, H.S., and J.R. Bulau, Equilibium fluid distribution in an ut tramafic partial melt under hydrostatic stress conditions, $J$. Geophys. Res., 84, 6109-6114, 1979.

Waff, H.S., and U.H. Faul, Effects of crystalline anistropy on fluid distribution in ultramafic partial melts, J. Geophys. Res., 97, 9003-9014, 1992.

White, W.M., and J.-G. Schilling, The nature and origin of geochemical variation in Mid-Atlantic Ridge basalts from the central North Atlantic, Geochim Cosmochim Acta, 42, 1501-1516, 1978.

White, W.M., A.W. Hoffman, and H. Puchelt, Isotope geochemistry of Pacific mid-ocean ridge basalts, J. Geophys. Res., 92, 48814893, 1987.
Wilson, D.L., Focused mantle upwelling beneath mid-ocean ridges: Evidence from seamount formation and isostatic compensation of topography, Earth Planet. Scl. Lett., 113, 41-55, 1992.

Wolery, T.J., and N.H. Sleep, Hydrothermal circulation and geochemical flux at mid-ocean ridges, J. Geol., 84, 249-275, 1976.

D. Bideau and R. Hékinian, IFREMER, Centre de Brest, DRO/GM, B.P. 70, 29280 Plouzané Cedex, France. (e-mail: dbideau@ifremer.fr)

(Received March 17, 1994; revised November 14, 1994; accepted November 29, 1994.) 